IMAGE EVALUATION

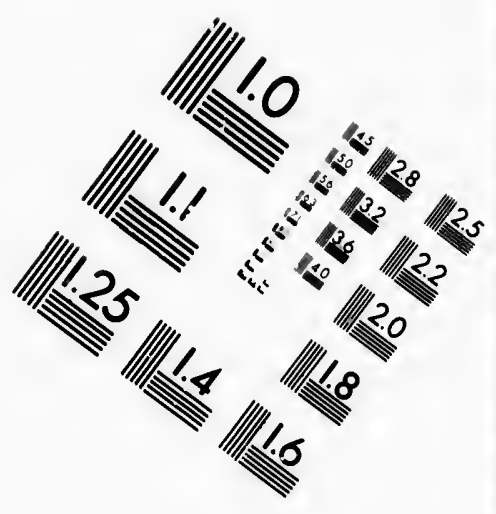

TEST TARGET (MT-3)
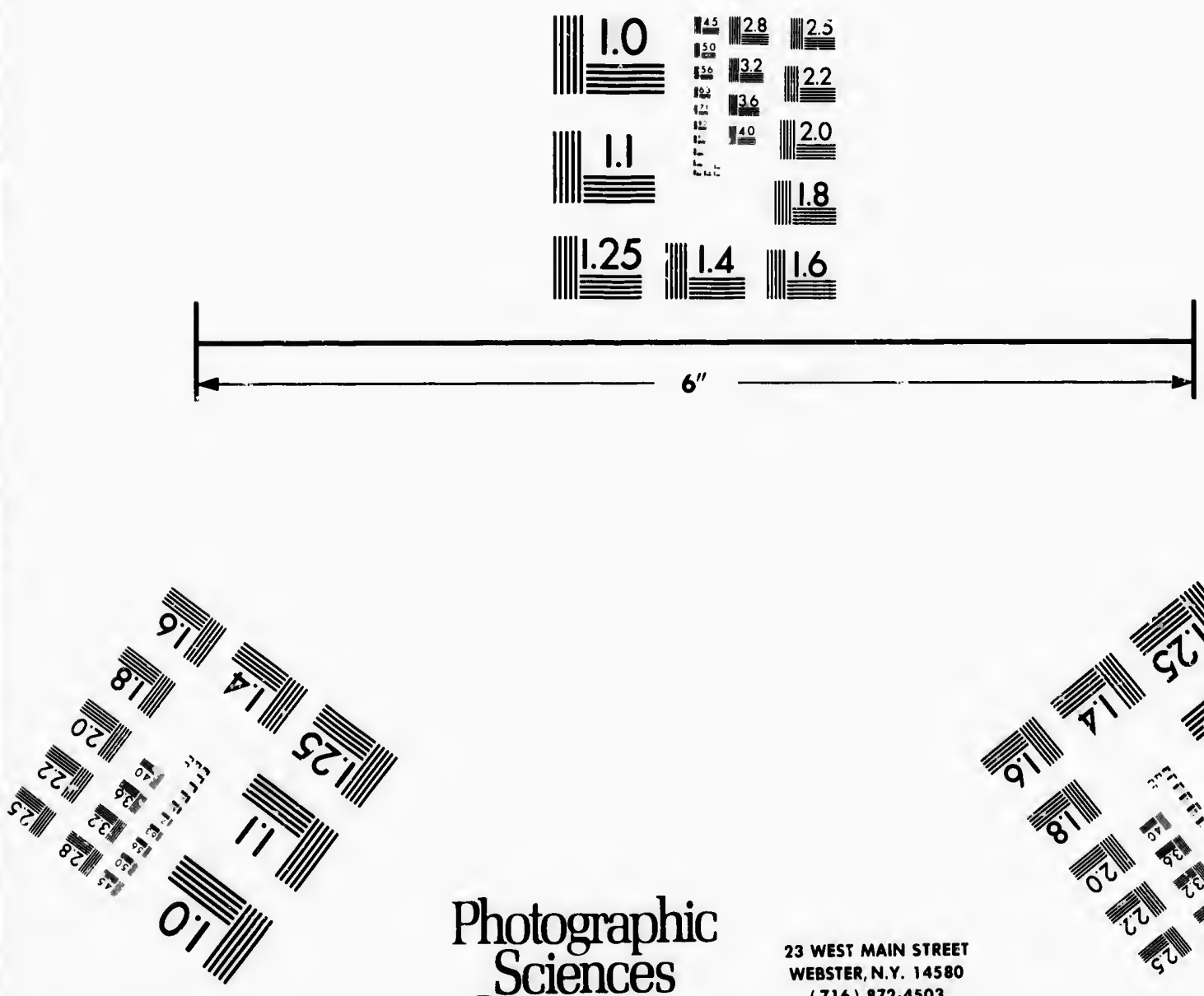

Photographic Sciences Corporation

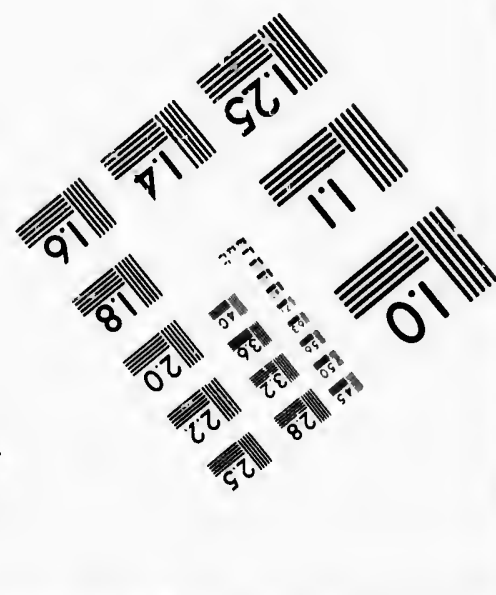




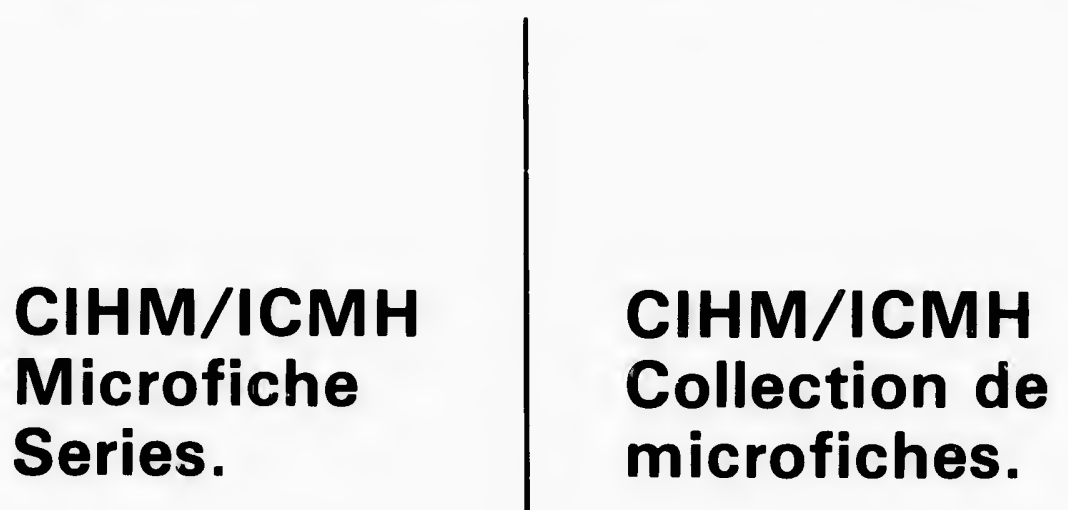

Carladian Institute for Historical Microreproductions / Institut canadien de microreproductions historiques
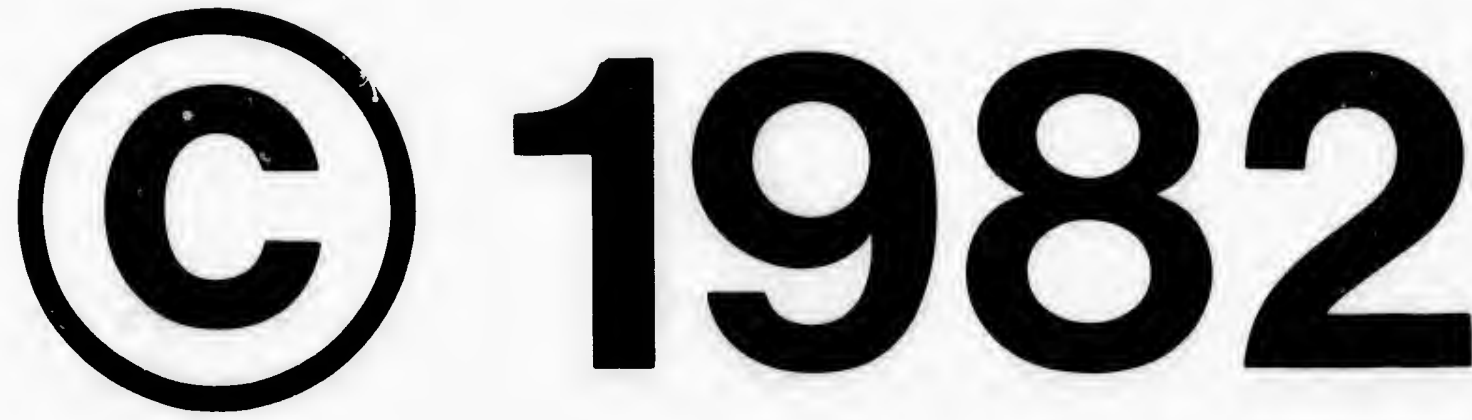
The Institute has attempted to obtain the best original copy available for filming. Features of this copy which may be bibliographically unique,

which may alter any of the images in the reproduction, or which may significantly change the usual method of filming, are checked below.

Coloured covers/

Couverture de couleur

\section{Covers damaged/}

Couverture endommagée

Covers restored and/or laminated/

Couverture restaurée et/ou pelliculée

Cover title missing/

Le titre de couverture manque

\section{Coloured maps/}

Cartes géographiques en couleur

Coloured ink (i.e. other than blue or black)/

Encre de couleur (i.e. autre que bleue ou noire)

Coloured plates and/or illustrations/

Planches et/ou illustrations en couleur

Bound with other material/

Relié avec d'autres documents

Tight binding may cause shadows or distortion along interior margin/

La reliure serrée peut causer de l'ombre ou de la distortion le long de la marge intérieure

Blank leaves added during restoration may appear within the text. Whenever possible, these have been omitted from filming/

II se peut que certaines pages blanches ajoutées lors d'une restauration apparaissent dans le texte. mais, lorsque cela était possible, ces pages n'ont pas été filmées.

Additional comments:/

Commentaires supplémentaires:
L'Institut a microfilmé le meilleur exemplaire qu'il lui a été possible de se procurer. Les détails de cet exemplaire qui sont peut-être uniques du point de vue bibliographique, qui peuvent modifier une image reproduite, ou qui peuvent exiger une modification dans la méthode normale de filmage sont indiqués ci-dessous.

Coloured pages/

Pages de couleur

Pages damaged/

Pages endommagées

Pages restored and/or laminated/

Pages restaurées et/ou pelliculées

Pages discoloured, stained or foxed/

Pages décolorées, tachetées ou piquées

Pages detached/

Pages détachées

Showthrough/

Transparence

Quality of print varies/

Qualité inégale de l'impression

Includes supplementary material/

Comprend du matériel supplémentaire

Only edition available/

Seule édition disponible

Pages wholly or partially obscured by errata slips, tissues, etc., have been refilmed to ensure the best possible image/ Les pages totalement ou partiellement obscurcies par un feuillet d'errata, une pelure. etc., ont été filmées à nouveau de façon à obtenir la meilleure image possible.
The c to thi

The $\mathrm{i}$ possi of thi filmir

Origiı begin the le sion, other first sion, or ille

The II shall TINU whicl

Maps differ entire begin right requil meth

This item is filmed at the reduction ratio checked below/ Ce document est filmé au taux de réduction indiqué ci-dessous.

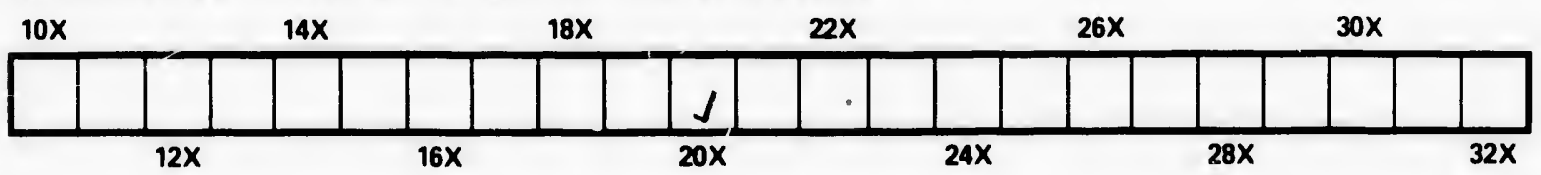


The copy filmed here has been reproduced thanks to the generosity of:

\section{Library of the Public Archives of Cenada}

The images appearing here are the best quality possible considering the condition and legibility of the original copy and in keeping with the filming contract specifications.

Original copies in printed peper coners are filmed beginning with the front cover and ending on the last page with a printed or illustrated impression, or the back cover when appropriate. All other original copies ere filmed beginning on the first page with a printed or illustrated impression, and ending on the last page with a printed or illustrated impression.

The last recorded frame on each microfiche shall contain the symbol $\rightarrow$ Imeaning "CONTINUED"), or the symbol $\nabla$ (meaning "END"). whichever applies.

Maps, pletes, cherts, etc., may be filmed at different reduction retios. Those too large to be entirely included in one exposure are filmed beginning in the upper left hand corner, left to right and top to bottom, as many frames as required. The following diegrams illustrete the method:
L'exemplaire filmé fut reproduit grâce a la générosité de:

Le bibliotheque des Archives publiques du Canada

Les images suivantes ont ét6 reproduites ovec le plus grand soin, compte tenu de la condition et de la netteté de l'exemplaire filmé, et en conformité avec les conditions du contrat de filmage.

Les exempleires originaux dont la couverture en papier est imprimée sont filmés en commençant par le premier plat et en terminant soit par la derniére page qui comporte une empreinte d'impression ou d'illustration, soit par le second plat, selon le cas. Tous les autres exemplaires originaux sont filmés en commençant par la premiere page qui comporte une empreinte d'impression ou d'illustration et en terminant par la derniere page qui comporte une telle empreinte.

Un des symboles suivants apparaîtra sur le derniere image de chaque microfiche, selon le ces: le symbole $\rightarrow$ signifie "A SUIVRE", le symbole $\nabla$ signifie "FIN".

Les certes, planches, tableaux, etc., peuvent être filmés à des teux de réduction différents. Lorsque le document est trop grand pour être reproduit en un seul cliché, il est filmé à partir de l'engle supérieur gauche, de gauche à droite, et de haut en bas, en prenant le nombre d'imeges nécessaire. Les diagrammes suivents illustrent le méthode.


\begin{tabular}{|l|l|l|}
\hline 1 & 2 & 3 \\
\hline 4 & 5 & 6 \\
\hline
\end{tabular}




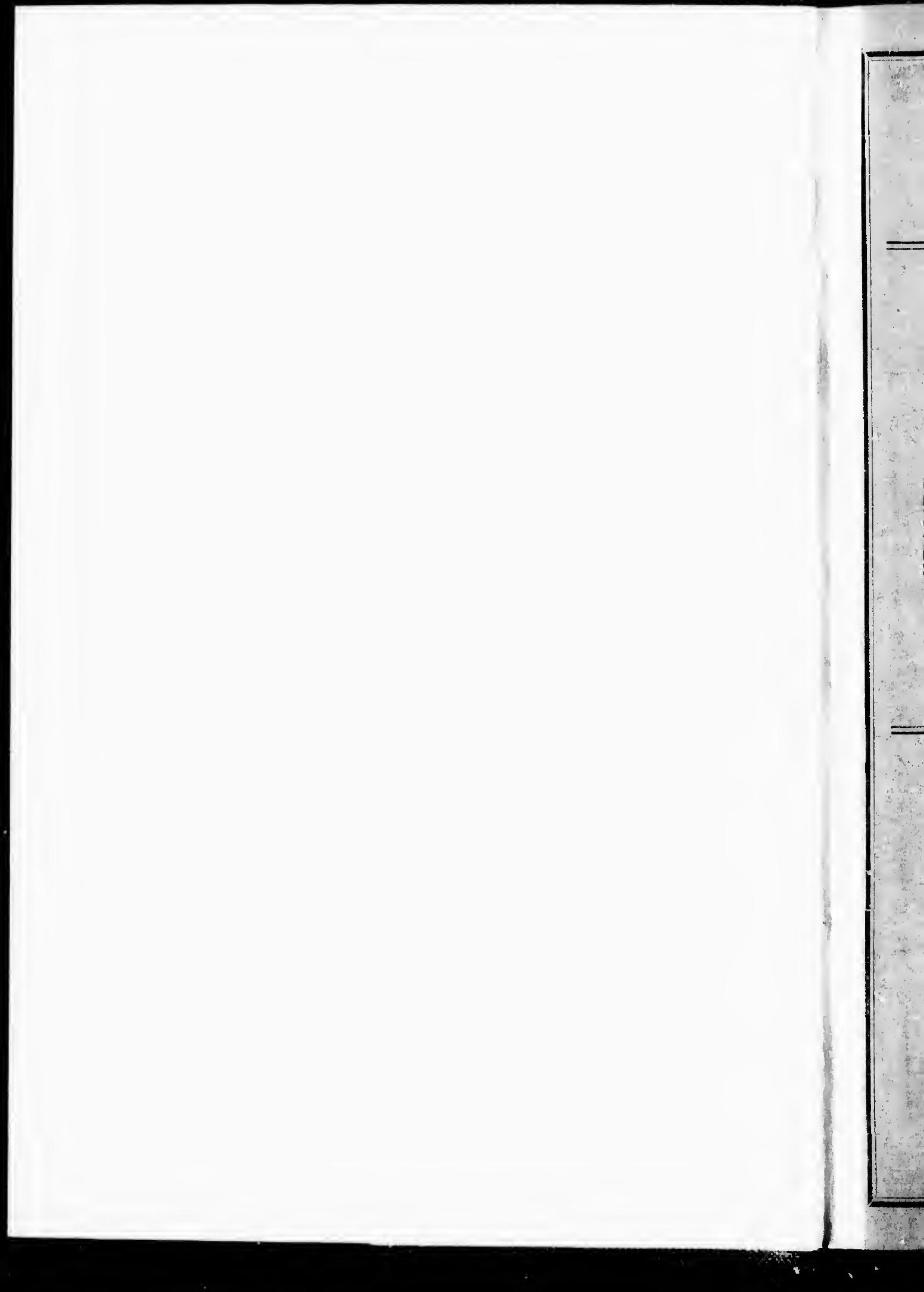




\section{ACROSS CANADA :}

A REPORT ON ITS

\section{AGRICULTURAL RESOURCES.}

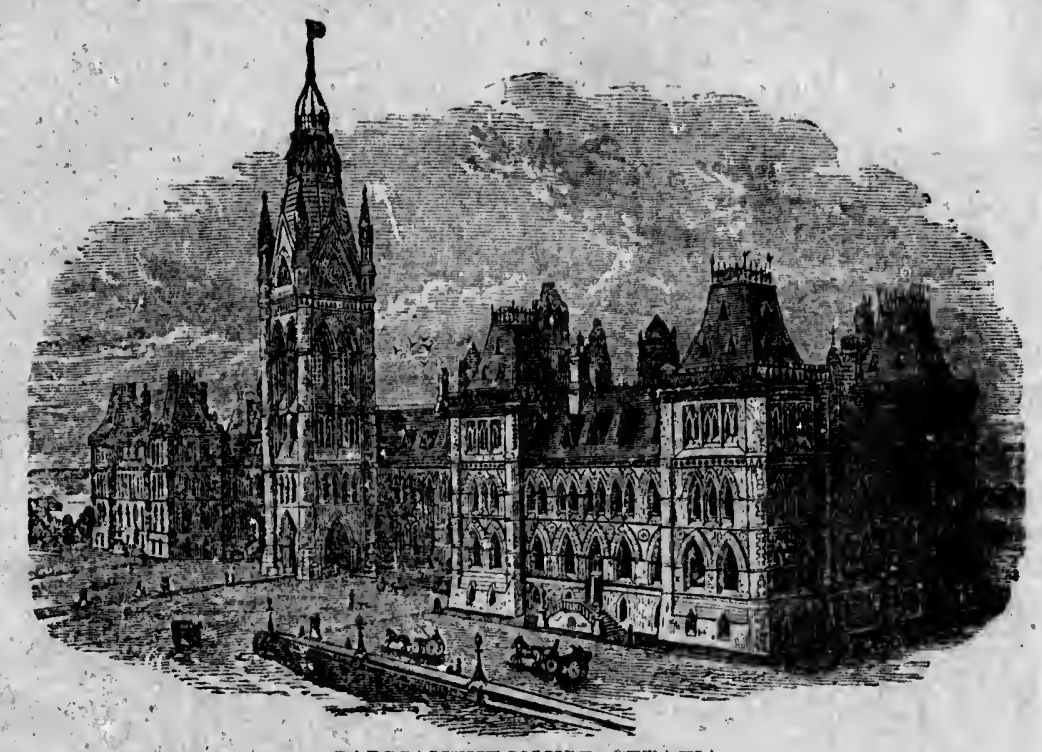

PARIIAMENT HOUSE, OTTAWA.

\section{- BY -}

WILLIAY FRE.II, B. Ic. Lond., F L. S., F. A. S.

Associate of the Royal College of Science, Dutlin ; Profossor of Naturat History in the College of Agricultural, Doweston, Salisbury, and Consulting Botanis

to the British Dairy Farmers' Association : formerly P'rofessor of



(ITTTER THTIOX)

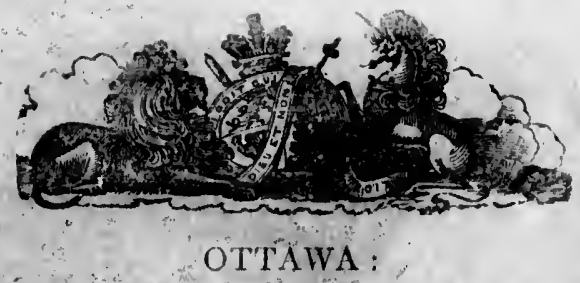

DEPARTMENT OF AGRICULTURE

I 886 





te idea of 3 whole of is nortl. from the which lies oal rivers. agricultu imated at re surface. ta of land miles, of 1, garden. :apable of 0 saly that irgin soil, le for the e miles, it yland and arly forty her words ropolitan itain can ied lands, 10 North tin : who ain: and

he writer ant from ! of the

Ninnip?g occupies ific coast tely, the eak first. ween the rom the But any $r$ to the 







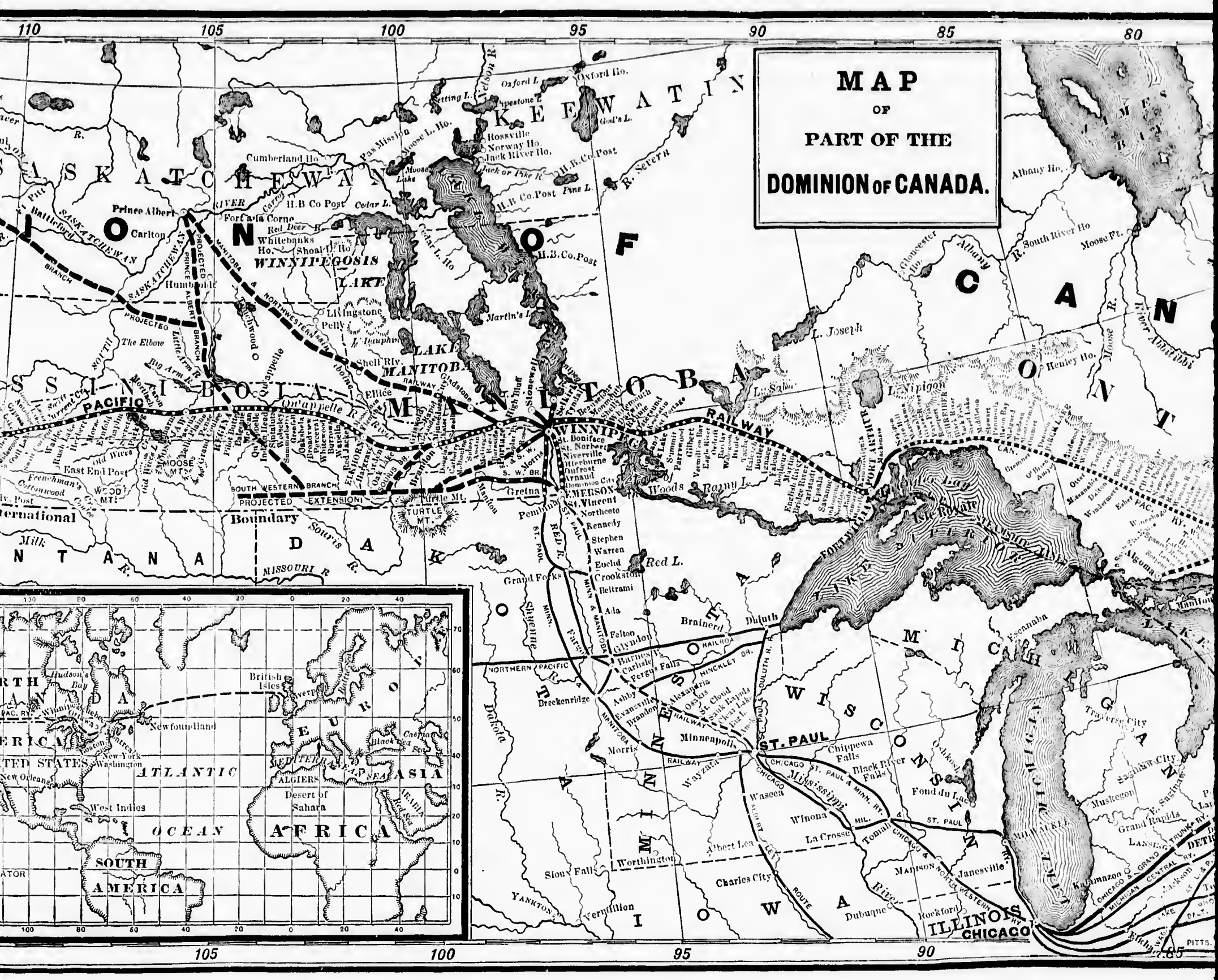




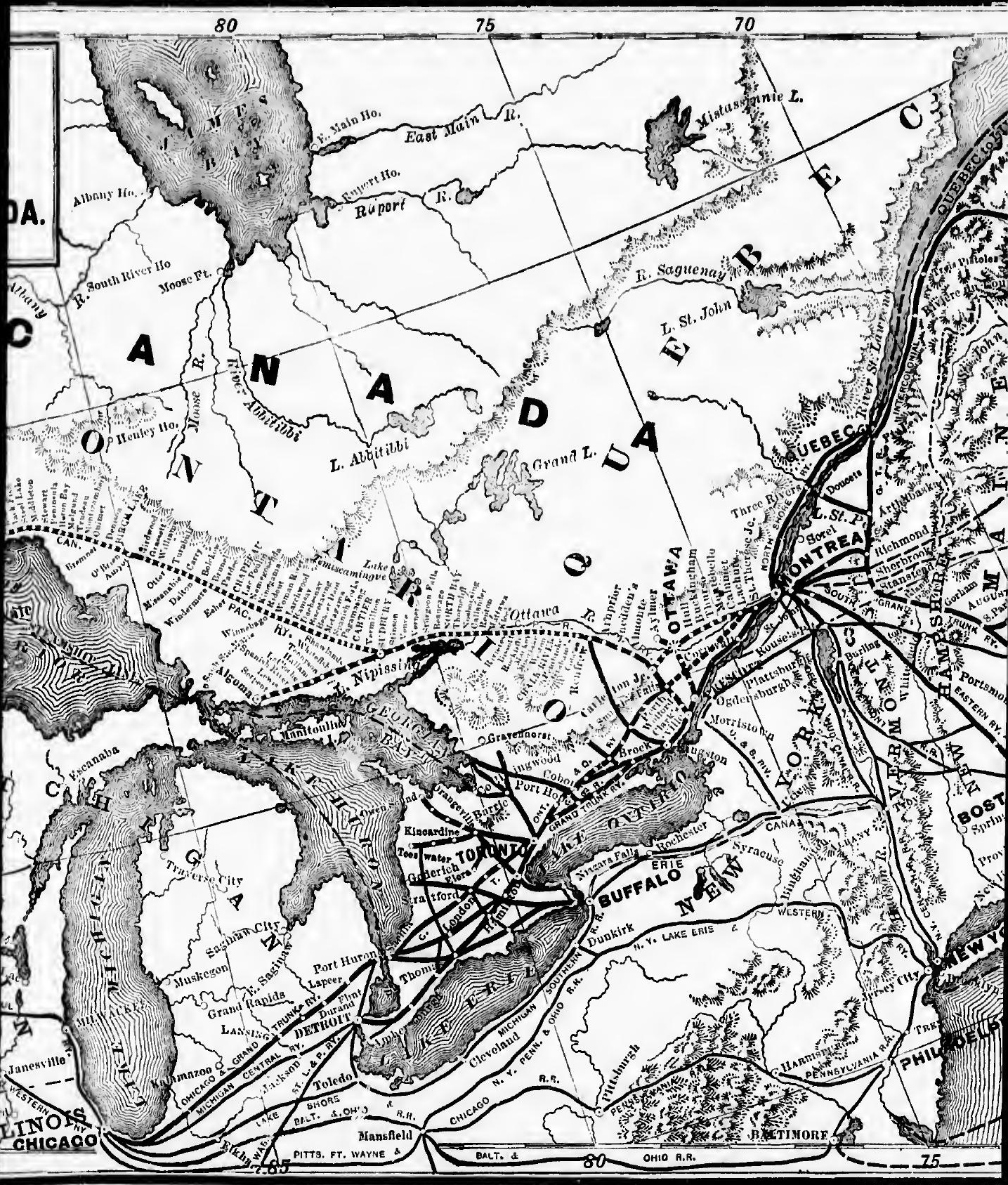




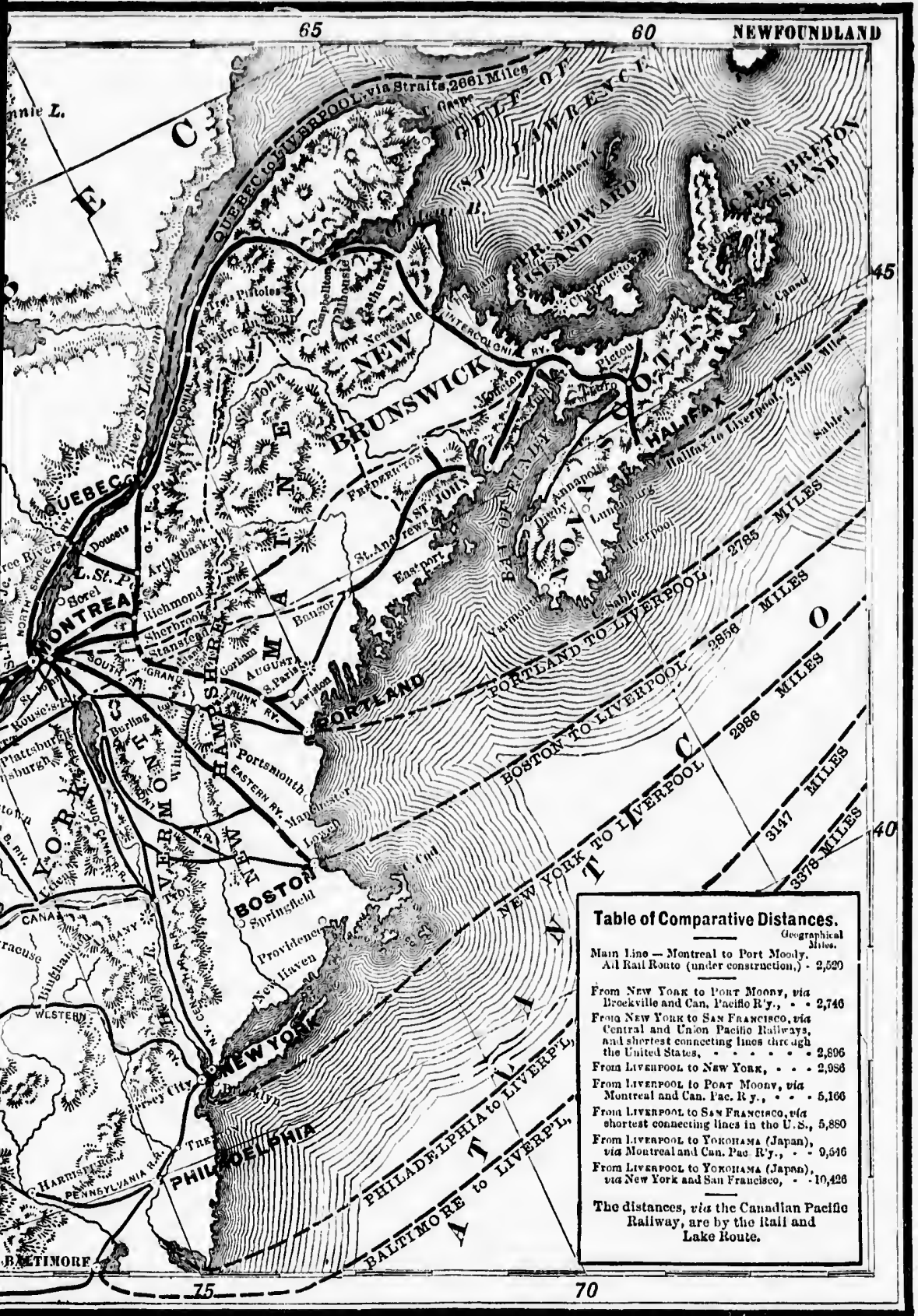



ern bou Atlantic letweer of vast ral capa iwo mil But frol actually which n (or orchi violding ipward and of 1 cultivat nuay be Wales million the pop Police spare ; and gat West p will ras along $t$

during each ot Rocky 


\title{
ACROSS CANADA
}

\section{A Iroport on ita Agrioultural Fosourcor}

\author{
INTRODUC'TION \\ *.
}

Cauada is so vast country that mere ligures fail to convey an arlerjuate ilea of its enormous extent. Taken in it entirety it is one-third larger than the whole of Europe. Southward it extends as far as lie latitude of constantinople, while is north. ern boundary is lost amid the ice-fields of the Arctic seas. From east to west, from the Atlantic to the Pacific coast-line, it stretcles a far giester distance than that which lies hetween Jiritain and Canada across the ocean. It is a land of hugo lakes and broad ricers. of vast grase-covered plains and dence forests, of rich mineral wealth and great agricultural capabnlities. The area of agrichiltusal and timbered lands in Canada is estimated at two millions of square miles, which represents rather mord than half of the entire surface. But from the returns of the last census, that of 1881 , it appears that the area of lind actually occupied at that time only slightly exceeled seventy thousand syluare miles, of which not more than one-half was improved, that is, covered by crops, pastures, gardens or orchards. Hence, of the two millions ur square miles estimated to bo capalsle of rielding their produce to the industry of the farmer or the forester, it is safo to say that iipwards of one million nine hundred thousand square miles still represent virgin soil, and of this, again, no less than ono million square miles are regarded as suitable for the cultivation of wheat. To give some idea of what is meant by one million square miles, it may be stated that this reprosents an area more tban eight times the sizo of England and Wales Scotland and Ireland put together. But, in the British Isles there are nearly forty millions of people, whereas in Canada thero are less than five millions; in other words the population of Canada is about the same as that of London (within. the Metropolitan Police District). Canada, then, has room for some of the pupulation whish Britain cau spare ; it is in nced of a frugal, industrious people who will till its vast unoccupied lands, and gather in the fruits which it yields, from the grain crops of Manitoln and the North West prairies, to the grapes and peaches of Ontario and the apples of Nova Scotia ; who will rase cattle, and eheop, aud horses among the foot hills of the Rocky dinuntains and along the fertile valley slopes of the great Saskatchewan Rirer.

The following pages contain some account of Caunda as it appearel to the witer during the early autumn of 1884 , in a journey which included points as far clistant from each other as the cost of Nova Scotia in tho east, and the Kicking Ilor:o Paus of the Rocky Mountains in the west.

An inspection of a modern map of the Canadian Dorninion shows that Winnip may fairly bo regarded as the most central city of British North America, for it occupies a position about equally distant from tho Atlantic coast on the east, and the Pacific coast on the west. It is of the country lying west and north-west of Winnipeg, namely, the Province of Manitoba and the North-West Territories that it is proposed to speak first. All this vast area lies to the west of the chain of great lakes which are between the Enited States and Cawada, and, indeed, Winnipeg itself is upwards of 400 miles from the nearest point of the shore of Lake Superior, the most westerly of these lakes. But any attempt to describe the country which stretches westward from Lake Superior to the 
Rocky Molintains would be incomplete were it not prefaced by some description of the great artery of communication which places the River St. Lawrence in clirect connection with British Columbia, and ere long will form a continuous and permanant overland route between the Atlantic and Pacific Ocenns.

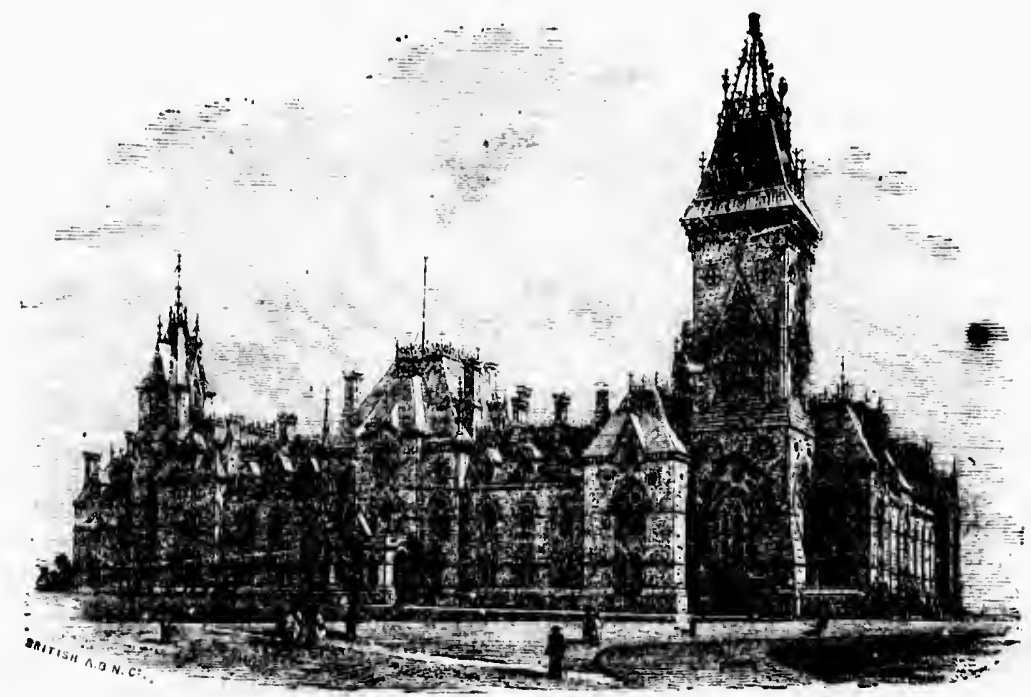

Depurtmentul Briltings, ottued-Eust blork.

iii i

CANADIAN PACIFIC RAILIVAY

cisarian

Whether we regard the Canadian l'acitic Railway as a monument of encrineering skill, or as a pioneer in the march of civilization, we are equally impressed with the gigantic rature of the undertaking. It spans a continent, and is, we hope, clestined to become 2 great commercial highway, not only between Britain aud the vast territories which the railway '.s perietrated and opened up, but between Western Europe and the countries, like Japan and China, which lie upon the Asiatic boundary of the North Pacific Ocenn in the far East. At present the eastern terminus of the Canadian Pacific Railway, is at tho:Dallousie Square Station, Montreal, in the province of Quebec, and the lengths of the various stages of the journey westward may be seen in the following table:-

\begin{tabular}{|c|c|c|c|}
\hline$\cdot$ & Miles, & & $\begin{array}{l}\text { Aggregate } \\
\text { Mileage. }\end{array}$ \\
\hline Montreal to Toronto... & . 333 & & \\
\hline 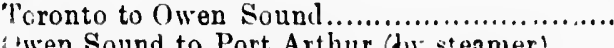 & . 121 & ...... & 454 \\
\hline "Wen Sound to Port Arthur (dy eteamer)....... & - 530 & ...... & $98 ;$ \\
\hline $\begin{array}{c}\text { Arthur to Winnipeg. } \\
\text { nipeg to Calgarv } \ldots \ldots \ldots \ldots \ldots \ldots \ldots \ldots \ldots \ldots \ldots \ldots \ldots \ldots \ldots \ldots \ldots \ldots \ldots \ldots \ldots\end{array}$ & - 429 & ....... & 1,413 \\
\hline 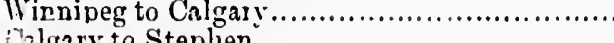 & . $83 !)$ & ...... & 2,252 \\
\hline lgary to Stephen.. & - 121 & ...... & 2,373 \\
\hline
\end{tabular}

At Stephen, in British Columbia, the railway reaches its oreatest height above the sea. Albont 5,300 feet, and at once commences to descend the Pacific slope of the Rocky Mountains. From Stephen to Port Moody, the terminus on the Pacific coast, the tract will be completed by the end of Octeber, 1585. Owen Sound is on the cost of Georgian Bay, which lies in the north-east of Lake Huron, and from this point to Port Arthur, on the north west coast of Lake Buperior, three powerful and excellently fitted steamers, the Alberta,"Alyoma and Athabasca meet the requirements of the line. But the Canadian Pacific Railway already possesses a complete overland route, for the railway connec-

Gover allotm other Rocky of Thi consid count Telfor of $\mathrm{Tel}$ 
tion of the connection it overland

ngineering with the lestined to territories pe and the the North ian Pacific uebec, and following

above the the Rocky , the tract Georgian Arthur, on steamers, the Canaay connec- tion lying to the nortl of the Lake Superior is complete, and open for trattic. With this intermediate portion, known as the Lake Superior section, and the remainder of the track on the Pacific slope of the Rocky Mountains, completed, the main route from Montreal to Port Moody will pass north of Toronto and the voyago across the lakes will be unneces-3ary, so that traftic will be booked right through from Quebec or Montreal to the Pacific coast of British Columbia with sut change of any sort. The distances will be 1 ho fullowing :

$$
\text { Miles Aggretote }
$$

Montreal to Callender ................ $347 \ldots \ldots$ -

Callender to Port Arthur................ $6,7 \ldots \ldots, \quad, 5,004$

Port Arthur to Red River.................. $428 \ldots \ldots, 1,4,2$

Red River to Summit of Rokies............ $9^{5}, \ldots \ldots, \quad 2,394$

Summit of Roclies to West Crossing, Columbia K... 13 I $_{3} \ldots . .2,532$

Wost Crossing, Columbia R. to Savona's Ferry.... 1 50 .... :,682

Savona's Ferry to Port Moody .............. 213 .... 2,S9;

The Red River atation in the foregoing iable is Winnipeg, and that at the summit of the Rockies is Stephen. As several of the lines of the Atlantic steamers land their passengers at Quebec it may be convedient to nention here that th $\rightarrow$ railway journey from Quebec to Montreal is 172 miles, but it is not unlikely that ere lon' all the ocean oteamers wiil lan 1 their passengers at Siontreal.

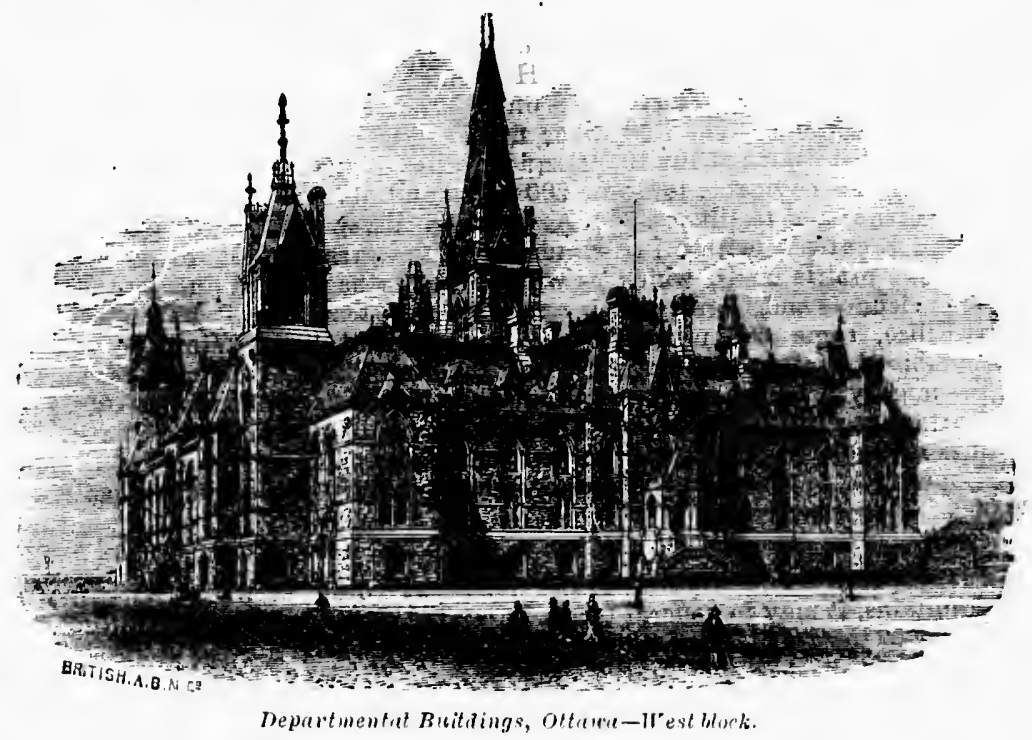

PHYSICAL FEATURES OF THE PRAIRIE

As large grants of land on either side of th $\rightarrow$ line have been made by the Dominion Government to the Canadian Pacific Railway, and as the railway authorities are offering allotments to settlers on very advantageous terms, some description of the geolocrical and other plysical features of the wide belt of country between Lake Superior and the Rocky Mountains may be of interest. After leaving Port Arthur, which is on the coast of Thunder Bay, Lake Superior, the railway passes tlirough a low, swampy country, with considerable timber. As Rat Portage, 297 miles west of Port Arthur, is approached, the country becomes more rocky in charaster, and this continues till the neighbourhood of Telford, 338 miles west of Port Arthur, and 91 miles east of Winnipeg, is reached. West of Telford station the rocks disappear and the line passes into the muskeg or swamp 
country, which in this district forms the eastern border of the great Red River plain. This owampy region, 20 miles in width, extends north and south for a considerable distance, and ia covered by a bed of peat some nine feet in depth. About 70 miles east of Winnipeg the great alluvial tract of the Red River Valley is entered upon, constituting the eastern Loundary of what is termed the first prairio steppe. This, like the other steppes to which referejece will be made, is a vast open plain stretching almost without oreak or interruption of any kind from horizon to horizon. It is in the middle of the rich agricultural lands affurded by the alluvium of the Red River Valley that the City of Winni. per, the metropolis of Manitoba, is situated, at the confluence of the Red aud the Assinibolue kivers. The line of latitude of Winnipeg runs very slightly to the south of the Land's End in Eogland, so that this city lies south of any town in the British Isles. The site of Winniprg is that of the old Fort Garry which was formerly the administrative. centre iu the Nurth Vest of the Hudson's Bay Company, so that, as a centre of distribution for the great North West, Winnipeg holds the same position as Fort Garry did in tho old fur-trading dnys. Its situation on the junction of two great rivers is a fact of immeuse importance in connection with the future commercial development 6 the vast prainie $r$ grion. The Assiniboine flowing westward emptses its waters into the Red River tlowing nurthward, and 45 miles north of Winnipeg the Red River discharges the mingled waters in to Lake Winnipeg, which is 280 miles long and 57 miles broad at its widest part, its coast liue beings nowards of 1,000 miles long, while its area of 9,000 square miles 18 yreater than that of Wales. At its northern exiremity the lake discharges its waters into the Nelson River which flows into Hudson's Bay at Port Nelson, from wheh point to Liverpool there is an osean passage of 2,941 nillos, being 100 miles less than the distance from New-York to Liverpool, notwithistanding that Port Nelson is on the eentral nortl and south line of North America. From the northern extremity of I.ake Winnipeg to Fort Churchill, another point on the coast of Hudson's Bay, and the probable terminus of the Hudson's Bay Railway, the distance is only 350 milez, which is less than that betwees I.ondon and Edinburgh. The Red River flows at first through the States of Minnesota and Dakota, and it drains about 10,000 square miles of the Province of Manitoba on its way sorthwart. It is navigable for some 200 miles, and its valley is covered with a soil of great excellence and fertility. The Assiniboine liver drains an area of about 66,000 square milcs, entirely within British territory, the greater port of the area being occupied by rolling prairie lands, which, as will here after be pointed out, are endowed with undoubted richness and fertility. It is navigable for steamers of 100 tons burden as far as Fort Ellice, some 600 miles from Winnipeg. But Lake Winnipeg not only receives the combined Waters of the Assiniboine and Red Rivers; it also receives the outllow of the mighty Saskatchewan, and altogether the drainage of some 400,000 square miles finds its way into this lake. Besides the main line of the Canadian Pacific Ratlway, four other lines run into Winnipeg and so enhance its importance as a great trading. centre. The population of the city of Winnipeg which, in 1870 was only 300 , had risen in. 1884 to 30,000 .

To retuin now to the description of the land extending between Winnipeg and the Rocky Mountains, it may in general terms be stated that the North West, from the Red River Valley to the foot lills of the Rockies is one vast fertile plain, the prairie, which for ages has afforted grazing lands te innumerable herds of buffalo which have to a great extent disappeared in the presence of the white man, but whose bones bleaching -n the prairie may still be seen in great numbers. As we have already explained, the prairie is enterel from Lake Superior through a belt of rough country with swamps, and streams, and rocks, and after crossing the muskeg or swamp which forms the eastern boundary of the led River Valley, the traveller paeses over three plains, or steppes, at different levels, on his progress westward in the direction of the Rocky Mountains. The Red River Valley form a portion of the first steppe, and it is occupied by a great lacustrine deposit 40 miles wide which extends right through the Province of Manitoba, from north to south. It presents a flat aurface of the most typical prairie lond, and is made np of the finest possible silt with a covering of black vegetable soil, which works up with great facility into cloice agricultural land. At Stony Mountain, near Winnipeg, and at Salkirk, 21 miles north of the city, cream coloured limestones affording a leautiful building stone are exteneively quarried. The first prairie steppe attains a height of about 800 feet abuve the sea, (the surface of Lake Superior is 627 feet above the sea), and

of

elir

by

no

du

bet 
plain. This

le distance. of Winniituting the her steples put oreak or o rich agriy of WinniIt the Assinibuth of the. a Isles. The ministrativeof distribuarry did in $s$ is a fact of: $t$ b. the vast Red River the mingled widest part, re miles is waters into. ech point to the distance entral nortl. Vinnipeg to. e terminus an that betis of Minnelanitoba on red with a a of about 3 area being e endowed ons burden not only eceives the ,000 square fic Ratlway; eat trading had risen in

nnipeg and st, from the the prairie, ich have to s bleaching: lained, the wamps, and he eastern steppes, at tains. The yreat lacusitoba, from $d$ is made ks up with peg, and at tiful build. $t$ of about sea), and. extends Westward as far as Macgregor, 79 miles west of Winnipeg, where, near the western boundary of Manicobs, there is an escarpment known variously as Pembiua, Riding, Duck and Porcapine Mountains. Whon 1his sloping escapment is surmounted, it is setn to be but the edge of more elevated plain, the secund steppe. which rises to a height of 1,(600 fect above the sea, and extends westward as far ns Mluose Jaw, 398 miles from IVinniper, comprising in its sweep the great plain of Regina and the celebrated Bell farn at Indian Head. The Railway, in ascenaing the gradient of the escarpment, follow's the Assiniboine valley, and on the second steppe the underlying rocks can only be seen in the scarped banks of the deeper river valleys, the surlace being covered by a great depth of drift. In the vicinity of Moose Jaw another slope, known as the Missouri Coteau, leads up to tha third prairie steppe, of which tha Missouri Coteau is, of course, the eastern edge. On approaching the base of the Coteau from the eas, aiross the second prairie steppe, a gradual ascent is made, amounting in a distance of 25 miles to "1pward of 150 feet. The-qurace now becomes more undulating in outline, and low litls formed of boulderstud gravel are seen. The belt of the Cotean is marked by the absence of diainage valleyi, and the pools and lakes on its surface becoming in consequence charged with saline matters, are sometimes spoken of as alkali lakes. The sulphates of soda and of magnesia, known popularly as Glauber's and Epsom salto, are the most abundant ingredient of the saline waters, and as the pools and lakes sometimes dry up towards ire end of summer, deposits of white crystals are left behind, which contrast in colour with the crimson tints of the marsh samphire, Salicornia, which grows around the lakes. Old Wives Lakes are of this saline character. The avernge elovation of Coteau above lio level of the sea is about 2,000 feet, and few of its hills rise more than 100 feet above the gentral lovel. The average breadth of the Missouri Coteau is from 30 to 40 milec, and it stritches diagonally across the central region of North America for a distance of about 800 miles, finging on the south the valley of the mighty Misseuri whence the Coteau take its name (French, Cóteau, a hill-slope.)

The third prairie steppe attaing an elevation of 3,200 feet, and eweeps in an almost unbroken plain from the Miseouri Coteau to the foot-hills of the Rocky Monntaios, wbich commence beyond Calgary, a rising town 839 miles weet of Winnipeg. Through this great plain the rivers have cut deep valleys, so that the view from the deck of a steamer is very limited ; this may bo well observed at Medecine Hot, 660 iniles west of Winnipeg, where the railway across tho south Saskateliewan River. There is evidence that within recent gealogical time the whole of the prairie area was extensively glaciated the numerous boulders scattered over the prairies printing to the transporting yower of moving ice. On the third steppe, some of the boulders appear to have been used in modern times by buffalo as rubbing stones, and they are surrounded by basin shapert depressions worn out by the feet of these animals. The two prairie escarpments to which reference has been made were cut by the action of running water, the higher one befort the period of glaciation, and the lower one at a later date by the waters of the now extinct lake wnich once occupied the Red River Valley. West of Medeciue Hat and a* far as Calgary the line passes along the west side of Bow River, over a plain heavily covered with drift. At Calgary the Rocky Mountains come into full view, and a railway journoy of 121 miles brings the traveller to the summit of tho grade, and to the water parting which separates the watershed of the Pacific from that of eastern slopes.

FORAGE PLANTS OF THE PRAIRIE.

The grrater or less value of land is to a creat extent deducible from the character of the plants which grow wild upon it. Save for more Scrub here and there, and low ehruds bordering swampy localities, the level monotony of the prairie is not of ten broken by any vegetalle groth which cannot be regarded as herbsge. Of true tries there are none,absolutely none, and much of the peculiar apper rence of this prairie in undoubtedly due to its treeless character. But this absence of trees is not without its advantage to eettlers, for the enormous labour invelved in clearing land of timber, which the pioueers 
In the more eastern parts of Canada hsve to iace, is unknown on the prairie. Indeed! as will be pointed out subsequently, one of the chief inducements the prairie offers to the settler is the sperdy return he geta for even his earlies labours. The herbage growing on the prairie differs much from that which grows on unbroken land at home, and it may be as well to mention hero some of the leading plants. Of the true grasses there are but few rpecies similar to those found in Britain, and of those lew it is somewhat rumarksble that one of the best is practically indentical with a species which has rarned a viry unenviable reputation at home, namely, cnuch grase, Triticum repens. Wherever there is marshy ground, or saline soils, this plant grows in abundance and makes a good fodder. It mout be rumarked, however, that the special character which makes cuuch grass so objectionable to Britith farmers in their arable lands, that is, the possession of long underground stems or stolons, is absent in the couch grass of the prairie which is ann-stoluniferoun, and, therefore, does not tend to form in the coil a dence bed or couch of proetrate, interlacing stems. Another British grass found on the prairie is our common meadow grass, Poa pratensis, which is there called red-1ep, or June grass ; this species is known in the United States as the Kentucky blus grass. Our fine bent grass or finrin, Agrostis vulgaris, also grows on the prairie, and is likewise termed red-top, or liv-land yasture grass. These two kinds of red-top, are found chiofly in the rastern prairies. The Best grasses of the salt marshes are Triticum repens, Spartina gracilio and Glyceria airoides. On the ligh, dry grounds the best fodder grass in Stipa spartea, the buffalo grass of the northern prairies whilst among other valuable species are Bouteloua - ligestachya, the buffalo grass of the southern prairies, and Triticum caninum, Bierochloo borealis, Andropogon scoparius, and Vilfa cuspidata. Tho bearded wheat grass, or dog, wheat,Triticum caninum, closely approaches couch grass in character, and Hierochla borealis is the holy grass of Northern Europe ; the latter possesses a most dolightful laverderlike odour, and is used by the indians in making mais which retain thelr fragramce for a long neri $d_{\text {. }}$ The common cultivated grasses of Britain, such as coksfoot, foxtail, timothy, and the fescues are unknown on the prairie, though it is highly probable they: will speedily be introduced. It is a noteworthey fact that the sedges, all of which are regarded as worthless at home, and are generally indicative of poor and undrained land, c.ntribute no inconsiderable part to the nutritive herbage of the prairie. The sedges belong to the genus Carex, and are easily recoguized by their solid triangular stems; the. most valuable sedges on the western prairies is Carex marcida, and on the eastern prairieg. the best are Carex aristata and Carex lanuginosa, none of which are foun $\mathrm{t}$ in Britain. In some districts the prairie hay consiste, almost exclusively of sedges. The summer food: -f horses which are grazing is chiefly Carex aristata, that grows in the inarsh latds; this sedge dies down with the appearance of :he frost of winter, and then the horses ge to the higher lands and feed on the grass, Ntipa spartea. Two other valuable grasses which deservo mention are the blue juint grass, Calamagrostis Canadensis, allied to the small-reed grass. of Britsin, and Spartina cynosuroides, a tall handsome species, found abundantly in the: sait mareh among the prairie plants worthy of note are Artemisia frigida, a low shruts with a powerful odour, and allied to our wormwood and mogwort; Eurotia lanata allied to our spinach ; Lathyrus venosus, the purple-flowered pea vine; Vecia americana, the purple prairie vetch ; Petalostemon violaceum, the "prairie clever," which is not a true clover, but only so called; and Oxytropis splendens. All these are fed upnn by animals when grazing, and the two first named are winter forage plants. In the fall of the year horses eat the hips of the prairie rose, Rosa blandn, a beautiful dwarf plant with. Howers poseseing the sweet odour of our dog cose, but with a ruddier colour. The prairie chicken (strictly speaking, the sharp-tailed grouse), is also very partial to these rose-hips, as woll as to the fruit of Elceagnus argenteus, a plant allied to the sea buckthorn of Britain. In June and July the prairie presents a briliant spectacle, for then most of the plants are in bloom, and near tho farmsteajs large areas are cut and made into prairie hay for winter feeding. The best proof of the nutritive value of the mixed herbage of tho prairie 18 afforded by the fact that for unknown ages the buffialo has roamed over and dwelt upon these plains; but this subject will be reverted to later on. I an greatly indelited to Professor John Macoun, M. A., F. L. B., the botanist to the Geological and. Natural History Survey of Canada, for much useful information which he gave me during our journey acrues the prairie."

Nor is the prairie barren of luscious fruite, for wild strawberries and raspberries grow in many localitioy, and besides attaining a good size, possess a fine flavour. Hops.

thrive $x$

Qu'App

held at

into a d West ha length 0 which a a width on every townshi

\section{4,28 ,}

25,27 ,

the Car

Manito

purpos 
Indeed! offers to herbage at home, o grasses is somerhich has $n$ repens. ance and or which $t$ is, the 8 of the ie soil a id on the or June Our fine termed 1y in the a gracilis irtea, the Bontelona Gierochloo or $\mathrm{J}$ oo ce borealis averderce for a foxtail, ble they: hich are ed land, - sedgess ms ; the prairieg. ain. In ter food: his sedg $\theta$ te higher deservo od grass in the w shrub $t a$ allied ina, the a true animals of the at with $\therefore \quad$ The ;o these ckthorn nost of o praiherbage od over greatly cal and. ave me.

pberries. Hopes thrive wherever there is sufticient undergrowth ; they are to be found in quantity in the Qu'Appelle valley, and some very fair specimens were shown at the Manitoba exhibition, held at Winnipeg in September, 1884.

\section{RRANTS OF LAND TO SETTI.ER:}

It would be forejgn to the purpose of this Report to enter at any great length Into a description of the manner in which the great region of Manitoba and the North. West has been measured and laid out in towaships. Eich township is a square, the length of whose sides is six miles, and it contains thirty-six sections of 640 acres each, which are again sub-divider into quarter sections of 160 acres. A road allowance, having a width of one chain, is provided for one each section-line running north and south, anit on every alternate section line running east and west. The following diagrain shows a township with the sections numberes :-

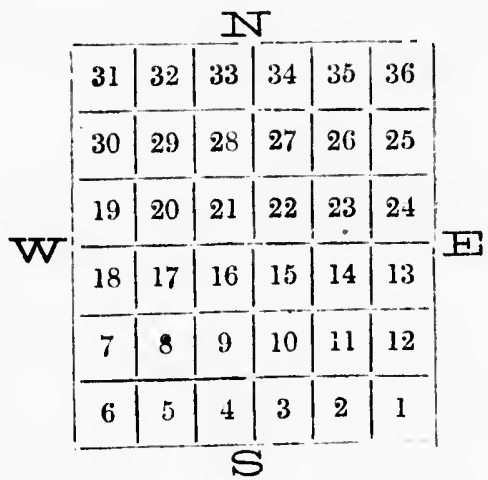

The sections are apportioned as folk w :

Open for Homestead and Pre-emptions. - Nos: 2, 4, 6, 10, 12, 14, 16, 18, 20, 22 $24,28,30,32,34,36$.

Canadian Pacific Railway Sections.-Nos, $1,3,5,7,5,13,15,17,19,21,23$, $25,27,31,33,35$.

Nos. 1, 9, 13, 21, 25, 33 along the main line, Winnipeg to Moose Jaw, are sold to the Canadian North.West Land Company, the balance of thcir lancis being in Southern Manitoba. purposes.)

School Sections.-Nos. 11, 29 (reserver by Government solely for scholl

Hudson's Bay Sections.-Noз. 8 and 26.

To assist in the development of the line the Dominion Government made to the Canadian Pacific Railway a grant of lands comprised within a belt extending, for a width 
of $2 ;$ miles, un cach side of the ling. All the old numbred sections, one square mile in area, wilhin this bclt are offered by ths company on vely fivourable terms to settlers. The balt, 45 miles wide, cxtends from Winuipeg to the foothills of the Rocky Mountains. a distance of about 900 miles. The fullest particulars of the inducements the conpany offers to settlers, accompanied by cliarts and $111 \mathrm{pss}$, my bs obtainel by writing to the company's general emigration arent, Mr. Alexander Begr, Canadian Pacific Railway, 88, Canuon Street, London, E. C.

THE VOLNG CITIES OF THE PRAIRIE.

The proximity of a railway is an import mnt factor in the masketing of acricultural produce, and it is not surprising to find that towns liave spruog up all along the line of th $\rightarrow$ Canndian Pacific Railway, but it is surprising to reflect on the rapidity with which some of these towas havo growa in siz 3 an 1 in importace, and how neat, business-like, and well laid out may of them appear to bo. As some as the centres of leading agricul: tural clistricts, it appears desirable to give a brief account of a few of the leading ones, taking them in the order in which they are eached by thy traveller in lis journey westward from Winnipeg. The municipal organization of some of these towns is very complete, and remarkably so when it is borne in mind that most of them are not more than two or three years old; they afford strong testimony of tho energy and capacity for business which characterizs tho dwellers in tho North. IYest.

Fifty-six miles west of Winnipeg the town of Portage La Praire is reached. It lies near the western boundary of the first stepuo, and occupies the central position of the richest wheat growing land in th 3 Prnvince of Mazitoba. It commands a very advantageous position, for, besides being on ths main line of the Canadian Pacific Ruilway, it is the so uth-eastern terminus and heal quarters of the Manit $\mathrm{jb}$ and Northwestern Railway. This line is projected to run in a north-westerly direction to Princs Albert, on the Saskatcliewan liver, a distanc 3 of 430 miles from Portage La Prairie; alout 80 mlles of the track are now ia operation, the stations proseeding from Portage La Prairie buing Miacdonald, Westbourne, Woodside, Cladstone, Neepawa, Bridge Creek, and Minnedosa. The last named place is about 30 miles due North of Brandon, a rising town on the Canadian Pacific Railway, and is situated on a tributary of the Assiniboine River. The Manitol)s and Yorthwestern Company has a grant land from th9 Dominion Govarnment of $2,750,000$ acres of forming and timber laads a!ongt its line of route, and chaap warrants for 160 acres or more, to be selected by the settler, may bo purch seseil at any of the oftices of the Alland R jyal Aail Steauship Conpany. In a dution to its position with reference to these two railways, Portage La Prairia possesses a further adrantage is that it lies on the north bank of the main Assiniboine River ; it is therefore likely to bscome an important industrial centre, and it already possesses paper and Hour mills, and a biscuit factory. The population is between three and four thousand.

Between Portage La Prairie and Carberry fifty miles to tha west, the line sceanda the gentle slope of the first escarpment, and Carberry, 106 miles from Winnipeg, is near the eastern border of the second prairie steppe. It is the county town of Norfolk, and is the centre of a fertile wheat-growing area called the "Beautiful Plaing." Althrough the buiding of the towa was only commenced less than two years ago, it now has a population of over 400 , and is already an important contre for the shipment of whsat.

Twenty-seven miles beyond Carberry the traveller arrives at Brandon, a beautiful town situated at the crossing of the Assiniboine River. Its fine buildings, and broad regular streets cannot fail to impress thg visitor, and it strikes one at once as a town of which it would be pleasant to dwell. It is the market centre for a considerable area in coutry, extending nortward as far as Minnedosa, and southward to Turtle Mountain, and there is much excellent land in the ueighbourhood. Near the railway are several large elevators for the reception of the wheat grown in the district. 
dare milo in to settlers. Monntains. no company ting to tlie fic Railway,

agricultural - the line of with which asiness-like, ing agriculeading ones, urney westvery commore than apacity for

ched. It lies tion of the y advanta. ailway, it is a Railway. rt, on the $t 80$ miles cairie bsing Minnedosa. wn on the River. The ovornment p warrants f the oftices $h$ reference it it lies on important it factory.

ne sceands peg, is near and is the $h$ the buidpopulation

, a beautiind broad town of le area in Mountain, are several
Brandon is 133 mules west of Winnipeg, and 47 milles farther on. the rising town of Virden is reaclied, whence a further run of 39 milies places the traveller at Moosomin, 219 miles from Winnipeg the line leaving the general trend of the Assiniboine River valley in vicinity of Virden. West of Moosomin, near Wapella, the track crossess the Indian tail from Moose Mountain in the south-west, to Fort Ellice, on the Assinibuine River, on the north-east. Moose Mountain forms hart of a group of dift hills known as the Weedy, Wolfe, and Squirrell Hills, and is a favourite place for settlement ; Fort Ell:ce, as has already been stated, is the point up to which steamers from Winnipeg car: vavigate the Assiniboine River. Favourably situated between these two point.s, and in the midat of a promising country, Moosomin appears to have a bright future before it. The Scoth crofters sent out last year by lady (iordon Cathcart are established in the district about ten inlles south of Wapelln. Each crofter liss a liomestead of 160 acres, and the settlemen is already on the ligh road to success.

Broadview, 164 miles west of Winnipeg, and 45 miles beyond Moosomin, is another well laid out towa, and the commercial centre of an excellent farming country - It occupies a pretty situation near the head of Wood lake, and workshops of the railwa! are established here.

Proceeding westward the line skirts the southern boundary of the Qu'appelle Valley, and 48 miles from Broadview the traveller comes to Indian Head, the station of the fa. mous Bell Farm, which is 312 miles from Winnipeg. The town of Indian Hear, which takes its name from the fact of the Indian Agency for the Qu'Appelle district being situated here, rejoices in a charming situation, possesses excollent natural drninage, and is the site of the finest brick hotel in the North-West. Wight miles north of the town are the fishing lakes of the Qu'appelle River, and a beantiful lake may be visited in a jour. ney six miles south of the town. The bell Farm affords a notable example of the capabilities of the prairie soils, and a full description of this remarkable ferture in the agricultural interprise of the North. West is given later on.

The town of Qu'Appelle is only 8 miles byond Indian Head, and is situated south of th fort of the same name. The Qu'Appelle liver is exclusively norih of the railway track, and it flows from west to east, pouring its waters finally into the Assiniboine Ri. ver near Fort Ellice. The town of Qu'Appelle was, until recently, called Troy, and the local authorities, in adorning its street with poplar street, have set an example which de. serves imitation in all ths prairie towns. The Government Immigration Buildings aro at $\mathrm{Qu}$ 'Appelle, and in the neighborhood of the town are numbers of excellent farms, both large and small.

After leaving Qu'Appelle, the next place of importance is Regina, 32 miles to the west, and 356 miles from Winnipeg. Ragina is not only the capital of the Provisional District of Assiniboia, but it is the metropolis of the North-West Territories. It is the head quaters of that fine body of men, the North-Western Mounted Police, who are entrusted with the maintenance of law and order over an enormous area, and, as the seat of government of the North.West, there may also be seen at Regina the Indian and Departmental Offices; and the residence of the Lieutonant-Governor. The Wascana River, or Piles of Bones, as it is also called, flows across in a north-westerly direction, and supplies the town with good water, Ragina possessing the largest and best constructed reservoir in the North. West. $A$ scheme is under concideration for constructing a railway from $R e$ gina in an almost directly northern direction, past Long Lake to Prince Albert, the town on the North Saskatchewan River which, it will be remembered, has also been chosen as the northern terminus of the Manitoba and North-Western Ruilway, which joins the Canadian Pacific Railway at Portage la Prairie. Regina is in the midst of the Great Plain of Regina, one of the largest continuous tracts of wheat-growing land on the prairie, the soil bing a rich, dark, clayed loam. With its publis buildınge, substantial houses, and wide open streets, the town cannot fail to impress favourably any one who may visit it, and it is likely to undergo rapid development. And yet, less than three years aso, there was nothing to mark the site of this rapidly rising city save a few canvas tents, and the silen. 
ce and solitude of the Great Plains of Regina had nover bece disturbed by the shri:k of the locomotive.

Journeying along west ward some shoice farming land is tutered upon after leaving Regina, and here the traveller commences the a.cent of the second prairie epcarpinent, the Mlissouri Coteau, marked by gently undulating land. At Mcose .Jaw, 42 uiles beyond Regina, aud 398 miles irom Wini ing, a very populous town is seached at the coufluence of the Moose Jaw and 'Tunder Creek-, tributairies of the Qu'Appelle River. The town i) neat and trim, its stceets and avenues are well planned, many of its buildiogs are hand. sone and substantial, and the growth of its population has been remarkablv rapid even for a praisie town. Fifieen miles to the north is Buffalo Lake, formed by the expansion of the Big Arm River on its way to join the $\mathrm{Qu}$ 'Appelle; the banks of the lake are about 300 feet lingh. From the town of Moose Jaw an lndian irail leads northwards to the Temperance Colony, about 160 miles distant, where the settlers occupy a rolling prairio well watered and fertile. Saskatoon, the capital of the colony, is on a wooded bluff, overlooking the broad Saskatchewan River.

Beyond Mocse Jaw the railway track fullows Thunder Creek, and continues to ascend the slope of the Grand Cotea'l of the Missouri. There are good pastures in this district, and the land looks well adapted for sheep grazing. T'wenty miles west of Moose Jaw the line passes the southern shore of the long, narrow Pelican Isake, which abounds in duck, geese and pelican. The summit of the Missouri Coteau is reached at a point 45 miles west of Moos $3 \mathrm{Jaw}$, and 443 miles from Winnipeg. At this point, called Secretan, the third prairie steppe is reached, and Secretan is furlher of interest in that the r o t easterly of the ten experimental farms of the Canadian Pacific Railway is situated here. The most westerly of the ten farms is at Gleichen, 351 iniles beyoud Secretan, and the history of this and the other farms will be fnund detailed later on. The railway track through the Cotea passes over some thirty miles of rolling or broken country, consisting of successive ridges and mounde, diversified will swales and alkaline ponds. To the south are the Old Wives Lakes, will Cliaplin Station, nine miles west of Secretan, at their northem end. The lakes, fifty miles long, and six to ten miles broad, swarm with wild duck. Gcing on wesward I he train passes Rush Lake, and arrives at Swift Current, 511 miles from Winnipeg. This small town is not far from the South Sastatchewan River, as it bends southward on its way to join the main stream. Forty-four miles further on is Cypress Station, lying to the north of the Cypress Hills. Around this spot is a considerable tract of bare, and apparently barren land, but as there appears to be plenty of useful clay resting on sandy eubsoils, it is very likely that goed agricultural soils may here be worked up, and the success of the experimental farms at Swift Current and Gull Lake gives support to this idea.

Forty-two miles west of Cypress is Maple Creek, 697 miles beyond Winnipeg, and more than 1,000 miles from the shores of Lake Superior. The creek takes its name from the quantity af ash-leaf maples which clothe its banks, and it is not unlikely that a considerable town may arise at this spor, inasmuch as the ranchers of Montana, the nearest of the states of the Union, find that they can save both time and money by taking their cattle through Canadian territory, driving them first to Maple Creek, whence they are taken by rail to Winnipeg, and then sent southward to Chicago. About thirty miles sonth-west of Maple Creek an Indian trail leads to Forth Walsh, one of the chief barracks of the North-Western Mounted Police.

Medecine Hat, 63 miles west of Maple Creek and 660 miles from Winnipeg, is beautifully situated on the east bank of the South Saskatchewan River, a short distance north of the point where this river receives the waters of its triburary, the Seven Persons River. With a present population of less than half a thousand, it is nevertheless a town which seems bound to make rapid progress, for it is the centre not only of an agriculturol area but also of what in the near future bids fair to become an important coal mining district. It occupies a great amphitheatre surrounded by low Cretaceous hills, the effect of which rising abruptly from the dcad level of the prairie is very marked, Medecine Hat is at a

River on recent bo ignited a utilized 106 mile farms ar ther on $\mathrm{i}$ direct no ton ; the River bet Edmonto on a clea miles dis expanse telope. $\mathrm{P}$ "porth-1 ned near traveller along the

$\mathrm{Ca}$

from 'Por feet abov for a gres the head for the in above all help to is town itse hills of $t)$ into relie derful co: deur.

$\mathrm{Tl}$

distance in this di Creek, ar abundan gion to st Edmonto River ov 
he shri:k of

after leaving epcarpinent, wiles beyond le roufluence - The town ogs are hand. - rapid even 10 expansion ke are about vards to the olling prairie ooded bluff,

continues to ures in this iles west of Lake, which reached at a point, called terest in that way is situaad Secretan, The railway ountry, cona ponds. To f Secretan, at swarm with vift Current, atchewan $\mathrm{Ri}$ miles further pot is a conbo plenty of al soils may pnt and Guil

innipeg, and es its namo likely that a , the nearest taking their nce they are thirty miles hief barracks

ipeg, is beauistance north orsone River. town which urol area but $\mathrm{g}$ district. It of which risHat is at a height of 2,100 ftet above the level of the ses, and the magnificent river which alds so much to the natural beauty of the locality has here carved out for itself a channel, the banks of which rise nearly 300 feet above the water. Immediately on leaving Medecino Hat for the west the train passes over a very fine iron railway bridge, which heie at a great height above the water spane the gorge of the South Saskatchewan. Away to the north-east of Medecine IIat this River is joined by the Red Deer River, while much farther in the same direction, on the banks of the Northern Sankatchewan, is the town of Battleford, between which and Medecine Hat communication is kept up along the lndian trail. Battleford is the centre of a picturesque regior occupied by many thriving settlements.

And now, weet of Medecine Hat and as far as Calgary, a distance of 179 miles the route lies through tho last stretch of genuine prairie land, - prairie land, too, of the most typical character, one sky-bound grassy plain, unbroken either by tree or shrub. Black.feet, Crees, and parties of other tribss of Indians are here met with. Beyond Medecine: Hat a broad table-land extends between the Bow River on the south and the Red Deer River on the North, and at Langevin, 35 miles west of the banks of the Saskatcliewan. a recent boring for coal resulted in the tapping of a heighly, combustible gas which was. ignited as it iseued from the earth and the heat evolved ras, in September last, being. utilized for driving the, steam machinery employed in the boring. Crow foot Crossing, 106 miles from Modecine Hat, takes its name from a weel-known Indian chief; a fow farms are established here, and there is also a large Indian reserve. Ninsteen miles further on is Gleichen, in the midst of a promising agricultural dis'rict, and almost on the direct north and south line between the important centres of Fort MacLeod and Edmon. ton; the former lying amongst the foot-hills southward on the barks of the Old Man River before it flows into the Belly River, a tributary of the South Saskatchewan, and Edmonton being far a way to the north on the banks of the North Saskatchewan. Here, on a clear day, the lofty, snow-clad peaks of the Rocky Mountains, more than a hundred: miles distant, may be seen glistening against the wcstern sky. Bgyond (ileichen is a finc expanse of unoccupied grazing land which, till recently, was the home of buffalo and antelope. Passing Cheadle, which is named in honour of the intrepid traveller who made the "north-west paessge by land," the western boundary of the thidd prairie steppe is attained near the banks of the beautiful Bow River, penetrating the outer valley which, the traveller pusbes on to Calgary, the most westerly of the genuine prairie to wns met with along the track of the Canadian Pacific Railway.

Calgary, 179 miles from Medecine Hat, 839 miles west of Winnipeg, 1,268 miles from Port Arthur, Lake Superior, and 2,250 miles west of Montreal, is more than 3,000 feet above the level of the sea. A small town as yel, it nevertheless possesses capacities for a great and rapid development : the centr $\mathrm{e}$ of a broad and fertile agricultural district, the head quarters of the large cattle renches to the south, tie future commercial centre for the mining enterprise which will ere long develop the country to the west wasd, and, above all the natural beauty of its situation,-these are some of ihe factories which will help to insure a great future for the town of Calgary. Eastward is tqe prairie, and the town itself is on the prairie; but to the north, to the south, and to "he wett, the foot hills of the Rocky Mountains break the monotony of the scene, and are themselves thrown into relief by the loftier summits in the back.ground, and these in turn present a won. derful contrast with the white peaks which tower above and behind them in awful grandeur.

Through the plain of Calgary flow the clear waters of the Bow River, which a short distance from the town is joined by its tributary, the Elbow. The excellen se of the land in this district is testified by the number of flourishing farms on Pine Creek, on Fish Creek, and on the banks of the Elbow River, and the plentiful supply of good water, the abundance of foel, and the kindly climate must continue to make this an attractive region to settlers. A journey northward by stage, occupying five days, is necessary to reach Edmonton the headquarters of the Saskatchewan trade of the IHudson's Bay Company.

West of Calgary the prairie contin sally narrows as it fullows the course of the $\mathrm{Bow}$ River over which the railway is carried no less than four times. Keith is the first station 
reached, aud next is Cuchrane, 20 miles from Calgary, where me the buillings of tog Sochicane cattle rauch. Ths $j$ )urney now begins to get more laborious as the aacending sarades becomes steuper in character. A tew miles farthar on is Morley, named after Dr. Morley Punsho1, and +till farther Wost the turbulent Kananaskis River is crossed. From this point the routo is through the (isp, and throngh Canmore, Duthil, avd Banft to Cas. tle Mountain, at tho foot of which, and on the banks of the Bow River, is Silver City, where there are numnerous indications of rich deposit of gold, silver and copper. Passing on through Eilion the traveller arrives at Laggan, or IIolt City, one of the most notley little towns conceivable. From this point a very steep gradient, about 7 miles in length, leais to Steplien, 5,800 feet-more than a milo-aloovo the level of the pea, and here, in the licking IIoras Pass in the highest point reached by the Canadian Pacific Railway. Before reachin: Steplın, which is 121 miles beyoud Calgary, the line passes out of the North. IVest territorius int J British Columbia, the Pacific prorince of the Dominion of Canada. stephen is about on the line of water parting between the Pacific and Atlantic slnpes of the Rocky Mountains and $n$ short distance beyond Stephen the picturesque Kicking Íore Iake supplies the Kickin Hurse River, which flows westward to join the Co. lumbia river, whose waters find their way into the lacific Octan. West of Stephen the construetion works of the railway are still in progress, the timber required being hewn from the well-wooded mountain slopes on tither sile, and floatea along the licking Horse Lake to a steam saw mill at its eastern end. On this lake, Canadian lunbermen may be seen at work guiding the log 3 in the desired course; the skill of the lum. berman is wonderful, he combines the sur efotedness of the nule with the agility of the cat.

SCENERY OF THE NORTH-IVEST.

It would be a hopeless task to attempt to convey any adequate idea of the ecenery of the Rocky Mountains. In approaching this superb range from the east the traveller experiences a succession of surprises, each one more novel than its predecessor. All the splendid and magnificent $\epsilon$ fl $\partial c t s$ which Nature can produce when she works with such materials as massive rocks and yawning chasms, lakes and streams and waterfalls, dense belts of dark green forest trees, dazzlings snow fields, and lofty ice-clad mountain peaks grlistening in the blue vault of heaven, are here combinerl to form a glorious nanorama which must limger in the momory of lim who sees it for ever. Dweliers on the prairie need never be more than a day or two's journey from regions were Nature may be seen in her grandess and widest moods. To tho south, and more particularly to the north of the railway belt, scenery widely different from that of the prairie may be enjoyed ; mind and body may alike be refreshed in the wild recesses of the Rockies, the Alp of the North-West ; and the country east of Winnipeg, between Lake Superior and the Red liver Valley, presents another complete change of scenery from that of the prairie. At Rat Portage, for example, 132 miles east of Winnipeg, the lovely Lake of the Woods is bound ere long to become a great place of ressort in the summer season ; nou oniy are its surroundings in the highest degree pictiresque, bat the surface of the lake itself is dotted with innumerable islands of every variety of shape ond size. These islands, tree-clads or grass-covered to the water's edge, are like

"Summer isles of Elen lying in dark purple spheres of sea,"

In 18

nience of se chewan, At north and 8 covers abou Nanitoba t of the line lyy the bou occupies th Saskatcher on the wes hy the Ath in Assinio Saskatcher Emerson a $95,000 \mathrm{squ}$ miles ; anc inentipned is about 12 district is

It $s$ the agricu rolling pr: in the ran from Bray selves as $v$ as to the a trict of $w$ of points indertaki

and upon them, and in the waters around them, the tired worker will find rest and en. joyment. More to the east, abont the shores of Lake Superior, are many of the scenes of Iliawata.

It must not be throught that the Canadian Pacific Railway presents in its outward ceatures much similarity to one of our English railway. The iron road that spens the 
ling of tog he arcending hed aficer Dr. rossed. From Bantl' to Ciss. Silver City, er. l'assing on notley little length, learly d liere, in tlio ilway. Bofure f the Nortli. on of Canada. tlantic slopes sque licking join the $\mathrm{C}_{0}$. of Steplieu oquired being eá along tlic anadian lun11 of the lum. ity of the cat.

of the scenery the traveller ssor. All the ks with such terfalls, dense untain peak. us nanorama on the prairie may be seen the north of ijoyed ; mind Alp of the and the Red 8 prairie. At the Woods is c only are its tself is dotted tree-clads or

rest and enof the scenes its outward at spens the prairie passes through no cuttings and over no embankments, except at the stations it is $r$ single track, it runs very slightly above the lovel of the rest of the prairie, and his $n$, houndary face on eitler side. The locomotive, an is customary in Ainerica, carries, in front a cow-catcher to clear wandering animals of the track, though these generally take to their heels at the sound of the deep, hoarse whistle, or of the fill-toned bell, butli: w which the driver can call into requisition if necessary. Side be side with the railway, anotlier emblen of letter-day civilization stretches across the continent,-the telegrajih wire. As the traveller speeds onward over the level plain ho notices hut few signs of life though now and again a tlock of prairie blackbirds or a flight of wild luck :may enliven the air, while here and there a gophor, or " prairie dog," may bo soen scainpering alon"? the ground. A great silence prevails, and away from the settiements there many be notliing to lureak the dead level between tho eye of the spectator and the hori\%on. Here, on a clear day, the horizon is so well defined, aud the contrast in appearance between lanct and sky is so marked, that ono gets a conception of the vastuess of tho blue vault overhead such as can never be acquired on the ocean.

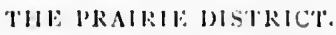

In 1832 the southern portion of the Nortl- West Territories was, isl the couve. nience of settlers, partitioned into four provisional districts, namely, Assiniboia, Saskatchewan, Athabrece and Alberta. The western houndary of Manitobn lies on a line drawn north and south through Fort Ellice, and between Virden and Moozouin. Manitolua covers about 123,000 square iniles; Assiniboia extends westward from the boundary of Manitoba to the meredian of Langevin, on the Canadian Pacitic liailway, alout 500 nile. of the line passing through it, and both this district and Alberta are detined on the south by the boundary between Canala and the Lnited Stites. 'l'h 3 district of Saskatchewan occupies the region to the norlh of Manitoba and Assiniboia, while Alberta lies batween Saskatchewan and Assiniboia on the east, and the central ridge of the Rocky Mountains on the west. Athabesca in the destrict north of Alberta, its eastern limit being formed by the Athabasca and the Slaves rivers. The leading towns are Regina and Medecine IIat, in Assiniboia ; Calgary and Edmonton in Alberta ; and Battleford and Prince Albert iu saskatchewan. In Manitoba the chief towns are Winnipeg, Portage la l'rairis, Brandon, Emerson and Gladstone. The areas of the four provisional district are; of Assiniboia, 95,000 square niles; of Saskatchewan, 114,000 square miles, of Alberta, 100,000 square uiles ; and of Athabasca, 122,000 square miles. For the salio of comparisna it may be mentipned that the total area of the British Isles (England, Wales, Scotland and Ireland) is about 121,000 square miles, sc that, roughly spaking, it may be said that each of these district is nearly as large as the whole of the United Kingdom of Great Britain and Ireland.

It seems desirable at this stoge to enter some what more fully into a description of the agricultural features of the North-West. The rich wheat lauds of Manitobs, the rolling prairie west of Brandon with here and there its alkali laker, the vast grazing lands. in the ranch courtry south and west of Calgary, the fertile belt that stretches north-west from Brandon and through the Saskatchewan valley towards Edmonton, all suggest themselves as wortlyy of diszussion. As, however, considerable information is already available as to the agricultural capacities of the Red River valley and generally of tho fertile district of which Winnipeg is the centre, it may be advisable to give detailed reports only of points farther west. Amongst these, the Bell Farm, both from the magnitude of the undertaking:and the significance of its results, deserves the first place.

THE BELI, FAR.I

The headquarters of the Bell Farm are at Indian Head station, 312 milles west of Winnip' $g$, and the far $m$ is comprised in the operations of the Qu'Appelle Valley Farming 
Co. It covers in all an area of 56,000 acres, and was organised in the year 1582, when breaking of the sod was commenced. In 1883, the area of wheat grown was 4,000; it was sown without backsetting, and geve an average yield of busheln an acre. In the present year, 1884, there are 7,000 acres under wheat, and next year it is proposed to have no less than 14,005 acres of wheat. The harvest is usually over by the middle of Auguat, but these year the season was somewhat backward, and harrest operations were in full swing in the middle of September. Thirty-eight reaping machines were at work simultaneously at the ingathering of the crop, and the sheaves as they come from the self-binders are left in tho field for a day or two, and then carried to the threshing machines, so that tho wheat nevor goes into stack. The grain is delivered from the threshing maclines into large wooden gramaries erected in the fields, whence in winter it is sleighed across "hy snow to the elevators adjacent to the railway.

The soil is a dark-coloured ciay loam of great depth, and a 3 horse team with a enlky plough, working on a 16 inch furrow, can turn up two acres a day, the cost on the Bell Farm being 1 doliar 90 cents por acre, equivalent to 7f. 1ld. The seed is sown broadeast on the rough fallow in March, at the rate of 1,3 bushel per acre, and this is followed by two or thiree hurrowing.

It was found practicable, with the machines alreacy mentionned to cut as much as 800 acres of wheat per day, so that at this rate the entire 7,00 .) acres could be cut in nine working days. The yield this year was expected to be 25 bushels an acre, and, on this estimate, it would not cost more than 33 cents per bushol to grow, which is exactly equivalent to 1ls. per quater. Thie manager of the farm, Major Bell, believes he can grow wheat and place it on the wharves at Liverpool, at 23 per quater, this priee inclading 8 per cent, interest on the working capital involved, and nny thing realiser above 23s. representing profit.

About 300 horses were found necessary this year, through and the summer they are occupied in breaking new land or in ploughing fai.uw land for the next apring's sowin ter's frosts closed the plouging season. A good heavy cart-horse weighing, say, 1,400 lbs., costs from 180 to 190 dollars, or abont £3s. In summer, 135 men are employed, and about half this number in winter. The summer labourers are paid at the rate of $30 \mathrm{dol}$ lars ( $f 653$.$) a month and all found. The resident labourers get a cottage and one acre$ of land free, with 35 dollars a month in summer and 30 dollars a month in winter. The first foreman gets 50 dollars a montly, and the four head foreman 40 dollars a month each, and all found. The farm 18 worked in five divisions and Major Bell telephones instructions to each division from his residence every evening. The hours of work are from $i \mathrm{a} . \mathrm{m}$., to $6 \mathrm{p}$. m., with ono hour out.

This season the farm also grew 500 acres of oats, which yeild from 50 to 60 bushels per acre, and are largely used in feeding the horses; also 400 acres of flax, the sced from 'which would sell at 75 cents a bushel, and the land would go into wheat. This summer 1,400 tons of prairie hay were get in, and for this it would be simple necessary to mow the prairie.

An examination of the standing wheat at har vest time showed it to be a good, clean regular crop. Only one variety was grown, that known as Fyfe, or No. 1 Hard, and it yielded a dry, bright, marketable sample. No "docking" or weeding of any sort has yet been found necessary, and there is no trace of the red hoppy which is such a pest in English corn-fields. The straw is of fair length, beautifully clean, and quite free frem rust. Only sixty head of cattle are kept and the straw is mostly burnt. A good example has been set at Bell Farm, in the planting of trees; last spring 25 miles of poplar trees Fere set out, they cost 10 cents each and were planted 20 feet apart, so that the cost per single row per mile was 20 dollars, equivalent to $£ 58 \mathrm{~s}$. $4 \mathrm{~d}$.

Frol latter plac 
2, whon , 000 ; it In the 1 to have Auguat o in full r simulself -bin. hines, so ling masleighed

a with a st on the is sown 1 this is

much as $t$ in nine on this tly equian grow luding 8 3s. repre-

aer they ag's sow. the win,400 lbs., ed, and f 30 dolone acre ter. The nth each, tructions i a. m.,

0 bushels iced from summer to mow

od, clean $d$, and it sort has a pest in reo frem example plar trees cost per

Thy Experimental furmo of the Csuadian l's ific Ruiway origioated iu a desire to refuse certain rumours to the eff, ct that thig territory between Mloose Jaw and Calgary, a distance of 441 miles, was unfit for cultivation. To settle this point the authorities aclopted the very bold expedient of'establisling a number of experimental farms along the railway track through the district in question. On Octoler $12 \mathrm{th}, 1883$, a train composed c 14 rars and locomotive left Winuipeg fur thg west, and it cintained teams, men a d outfit necessary for establishing the left farms. The site for each farm was only selected the day before the thirty teams wera set to work on it. Tho originat intention

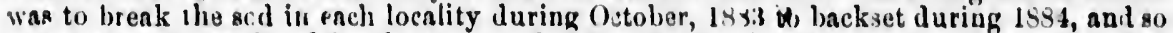
jrepare a good seed beit fir the sjuring of 1855. But. Eo impressed wure those who had charge of the work with thi churacter of the soil, that they determineil to riek tha attempt of raising, crop, direct.ly of the sod. Accordingly, at thig end of Marel, this year another train left Winnipeg with seed and all facilities for sowiug, and during August and Sep. tembar the crops were liarveated and the yiell ascertained. Thi results of these plucky experimenta, and other cletails respecting the ten farms are collected in the following t.al)le, which is self-explanatory : -

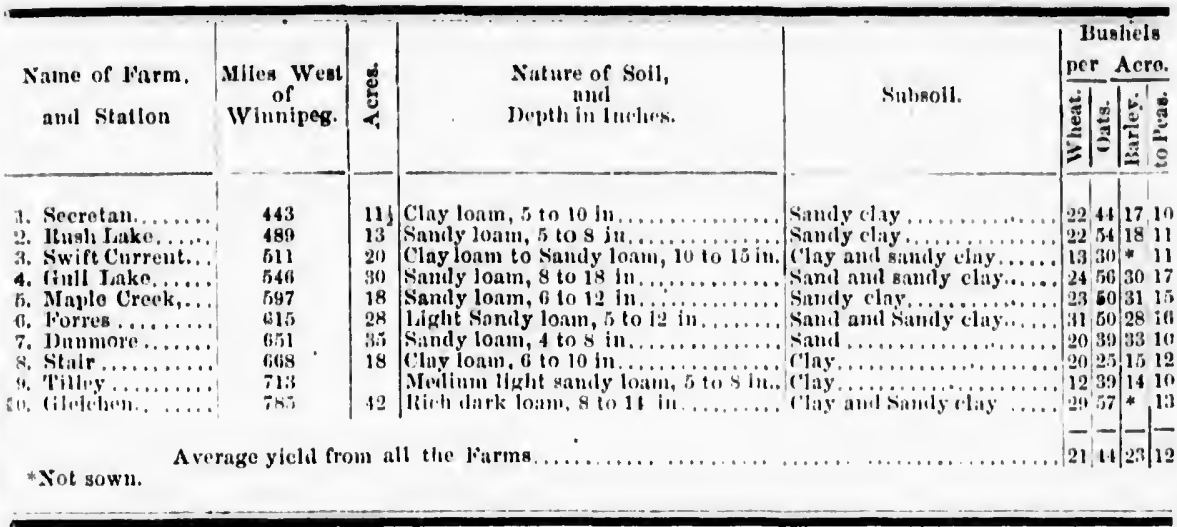

In considering these satisfactory results it is b.at f sir to bear in mind the very priinitive style in which the land was cultivated, and furcher to remember that there was no constant a pervision of the farms. It is reasonalole to conclude that these farms, and others like them, for out on the western prairie, and at elevationg varying from 2,000 feet to 3,0.0 fect alove the level of the sea, will under proper cultivation yield results not inferior to those obtained in the plains around Winnipeg ; And it is further wortliy of note that many of the regions on the third pririe steppe and all the experimental farms are on this steppe - offer considerable facilities for grazing, so that it is likely that mixed farming will soon be established herc. Takes, for example Maple Crcek. In this district stosk winter out, and thrive well on the herbage growing on the slopes of the Cy jress IIills to the south. M Ich of the Cypress Hill regions appears to be admirab'e sirited to grazing and dairy fa:mirg, anil no doubt to sheep raising. Gleichen, again, is in the middle of a district which lnoks woll adapted to steck raisin: $\%$ and dairy farming.

\section{THE RAYCHES.}

From Maple Creek to Dunmore the railway runs almost due west, but near the latter place it turns to the north-west, and practically retains this direction up to the 
summit level. Iad it continued straight on it would have passed to the south of, or right through, the anch country; as it is, the cattle ranches are on the south and west $\in f$ the track. At present, then, the ranch country lies between Calgaay on the north, io: $t$ MacLeod on the Belly Rirer on the south, and the Rocky Mountains on the west. Cattle, and horses have hi: 1 erto been the chief consideration of the ranchers. Sheep are, however now beginning to receive attention in certain districts. The life of a "cow boy" is a hard and sometimes a severe one but it is an active, healty existenec, which many a hardy young fellow would no doubt prefer to a sedentary occupation at home, especially if he saw some prospect of stasting farming on his own account. A cow boy's outfit comprises a. California sad lle, with tapaderos (fittings) complete, a rifle on the saddle, a pair of schapps (leather leggins), a pair of Mexican spurs, an overcoat, and a cow boy hat or soft sombrem. No doubt to the cow boy in these western wilds.

\footnotetext{
T'is pleasanl to track the roving herd

On a long, bright summer day*

To camp at night by tho lomely creek,

Where dios the golden ray.
}

The Canalian ranchers have heen fortunate in having no outbreak amongst their herds of the contagiou. diseases which have had such disastrous effects on stock keevers at home. This immlinity from disease is a precious boon which they will do well to gruard most jealously.

It is unnecessary to enumerate the ranches. The leading ones are about 100 miles south of Calgary, towards Afontana. At and around Cal rary the chief constituent of the herbage is the grass stipa spartea, and the fact.of one of the bistorts. Potygonum rivipa$r u m$, which is an Alpino plant, srowing freely here renders it doubtful whether wheat. growing would prove generally sucsesful though some good resilts have this season been attained in the cultivation of wheat wnd oats on a small scate. The plains about Calgary, like the foot-hills beyond, are however obvionsly destined to be a great stock-raising and possibly a dairing country.

There is a part of the North-West not yet opened up by railway entreprisu, but to which wistful eyes are already eagerly turned. This is the fertile and lovely district com. 4 rised in the valley of the Saskatchewan. The towms of Edmonton, Battleford and Prince Albert lie along this little known region, and the projected railway from Secretan, on the Camadian Pacific line, to Edmontou, would render the entire valley much more acccesible.

CLIMATR OH TIE PRAIRIE.

Nothing in connection with the North-West is, perhaps, more misapprehended at. home than the nature of its climate. Old notions, and particularly erroneous ones, die hard, and the idea, that up to fitteen or twenty years age was still current in England, that North-West Canada was a cold, desolate, inhospitable region, with its soil frost bound nearly the year round, and fitted only to be the home of fur-bearing animals, still lingers in the minds of many people. That in the North.West the thermometer as a rule gives higher readings in the summer and lower in the winter than we are accustomed to in the -!d country is perfectly true, but in estimating the character of a climate it is wrong and misleading to be guided by the thermometer alone. The atmosphere possesses other properties besides temperature ; it can tell a tale to other meteorological instruments besides the thermometer. The hygrometer, an instrument for indicating the amount of moisture in the air, should be observed in conjunction with the thermometer, or the same information may be gained by comparing the reading of a wet balb and a dry bolb thermometer. It is thereby ascertained that ihe air of Manitoba and the North.W drier than that of the Britioh and Isles, and to comprehend the significance of this fact

it is uces ductor of jheric nI renders $t$ in cold $w$ rapidly $\mathfrak{t l}$ British I yuently of lieat, insulator saturated produce. iterstand our owl

To expla gence int

serviceal in the ac ticles of of tilth impleme home, a clay soils tallow la zo effecti

a crops $\mathrm{C}$ duty to Manitol northwa mounte cers and West is by these Hinnij) men of term of are supl 'Tho rat day ( 20 . (langer there i gions in knowle of its $n$ ? the last nendat ther the Tlie he: Leod, I the No 
f, or right bat $\in f$ the rth, io:t st. Cattle, however is a hard a hardy ally if ha comprises pair of at or soft

ngst their $k$ keevers well to

100 miles ent of the $n$ vivipaier wheat. ason been t Calgary, ising and

isu, but to trict com. nd Prince $a$, on the accussible.

aencled at die hard, ind, that st bound ill lingers rulo gives to in the rong and ses other truments mount of the same alb theris unually this fact it $i$, nccessaty to bear in mind the well-known physical law that water is a better con. ductor of heat than dry air. The presence in the atmosphere of moisturi-and atuospheric moisture is nerely water vapour, often containing minute particles of waterrendess the air a better conductor of heat the higlier the percentage of moisture. Hence in cold weather, moist or damp air will conduct away heat from the aninal bojy more rapidly than drier air, and this arises the pronounced feeling of discomfort which in the British lsles is often associated with cold, damp weather, and nrobally much more fre1) uently experienced in Britain than in North. West Canada. Dry air is a ball conductor of heat, so ihat, even with a very low temperature, slich air really plays the past of an insulator in preventing the excape of warmth from the hody. Jeet it, lowerer, l) come caturated with moisture, and it would at once, by conductins the heat away from the skin, produce a sensation of cold and discomfort. On physical giounds, then, it is easy to un: Herstand how the dwellers North. West cand endure a winter temperature which iu our own climate wonld be intoleralie-the dryness of the atmosphere is their rotection. To explain why the atmosphere in so much drier there, would involve too great a divergence into physiographical details.

Horeover, the froet which locks up the ianc for months in the winter is really a serviceable friend to tho prairio iarms. The moisture which permeates the soil expandis in the act ef freczing, and this cause a minute separation or disruption amongst the particles of ploughed earth, so that when the thaw comes they fall a part in a desiralle state of tilth which it is well nigh impossible to bring about by the vork of any agricultural implemert. Frost is a good servant to farmers, and one that works without pay. At home, a winter witbout frost is regarded by farmers of arable land, particularly of heavy clay soils, as a misfortune; they now well that it means much extra work on their tallow lands for both men and horses, and that with all their pains they cannot produce co eflective a result as frost is capalsle of bringing about.

THE NORTH-WEST MOUN'TED POIICE

A few words on the prairie police will not be out of place. They are pratically a crops of horse-soldiers known as the North-Western Mounted Police, and it is their duty to cary out the law anit preserve the peace over a district stretching from the Manitoba buundary 750 miles westward, and from the United States boundary 250 miles. northward. They wear a bright military uniform including scarlet jacket, are well mounted on excellent horses, and carry carabine, sword revolver and cartridge belt. Offi. cers and mon together number less then six hundred, and yet under their care the North. West is absolntely safe, the Indians being particularly impressed with the power wielded by these guardians of the peace of the prairice. All enlistments are made at Fort Osionrne, Vinnipes, and a lubicants wist bu betwon 22 and 40 years of age, active, able-bodied men of sound constitution, and must produce certilicales of cxenplary character. 'The term of engagement is for live gears, and there is no buying out. Nembers of the force are supplied with free rations, free kit, and are boarded and lodged in the police barracks. The rate of pay varies from so cents a day 14s. a wetk) in the first year, to 70 cents a day (20z. $\mathrm{d}$, a week) in tho fifth year. The duties of the police are often associated with danger and fatigue which tax severely the physital powers, but for a strong healty man there is a certain cliarm about the life, and some who think of settling down in these re. gions wight like a five year's introduction before pitcling their tents. An excellent fnowledro of the country is obtained during a term of service in the force, but none of its members are permitted to combine the callings of policeman and farmer. During the last six months of their service they are allowed, upon the Cammissioner's recom. mendation, to make application for a homestead, and everything possible is done to further their interests in that direction, provided their du ties havo been satisfactorily performed. The headquarters are at Regina barracks; other centres are at Fort Walsh, Fort MacLeod, Battleford, Calgary and elsewhere. As the introduction of alcoholic liquors into the North. West is contrary to law, the policemen are charged with the enforcement of 
this regulation; and they often experience a long and severe ride across the prairie on the track of indions who seen to have an almost uncontrollable propensity for horse stealingr. Thes s aboriginal thieves are genertlly capturcd and punished. Last sejtember the prisoners I saw in confinement at Regina barrnck included "Sittir" Back." "Single Man," :The Rat," "The Rock," "Day Thunder," and "Frog's Thigh," all of them for stealing.

TIIE PRAIRIE IS A IIOME HOR SITTIEKS.

What advantage or inducements does the North-West offer to settlers ! Part of the answer to this question must ba sought in the foregoing pages, but I will enumerate here some of what I consider to be the chief attractions. Grants of land within convenient distance of tho railway may be obtained either free from the Government, or at very cheap rates from the Canadian Pasific Railway. These may ba selected from the ricliest prairie land at the choice of the settler. No cle rranse of timber is required, there is no severe labour with the axe, nor any patient waiting for years in order that tree stumps may rot to facilitate their removal. The prairie sod can be laid under a plough for the first time and a crop hirvested all within the space of the first twelve months. The country is well watered for, from what liss already been said,it is evident that rivers and lakes and creeks abouud, and where running water is not conveniently near, good water can be got within moderate distance of tlie surface. The prairie is lieality to dwell upon, the climats is more genial than is generally supposed, and settlers who go nut in robust health will fine the country is not only tolerable bat enjoyable to live in. Weak or clelicate people snould not go there, for they miglit find tho air too bracing. Idlers and loafers should not go there, becase the prairie is in need of thrifty workers. Men who wast to asquire wealth without working for it shonld not go there, because they will be desspointed. Thomas Carlyle once wrote, "Two men I honour, and no third -first, th z toil-worn craftsman that with earth-made implements laboriously conquers the earth anl makes lier man's" Men of this tipe will find on the prairio a wide field for conquest and l believe they may fell more certain of a reward and of a speedy reward, than in uine cases out of ten they coull hope for in the old country.

For a long time to come the welfate of the North. West must depend chiefly upon its agricultural development. And at present its agriculture is of a some, what primitive character, and does not demand much technical knowledge on the part of tha settler though"I am far from implying that seme farming oxperience a squired at home would not lis rery valable, especially in connection witl the mixed kinl of farming which I shall presently suggest. Strong men, who delight in work will get a good start, for at tho outset the great question for the settler is, how much can I plough? Anil lis might continne, for what I can ploumh I can sow, and what I can sow I can reap. But a settler would ba illadrised to hadertake tha cultivation of more land than he could conveniently. manage, a he would probably fall into sovenly farming, and so bring about a deterioration in the value of lits hollingr.

Wiinle I regard the Beil Farm as a valuable example of what can bs effected in wheat-growing on the prairie, I think it would be a mistake and a mistortune were the vast plains of the North. West convertot into nure wheat-producing lapils. They are capable of comething batier than this, or, at all events, of a more varied agriculturaldevelopment, and I would suggest to settler's that even at the end of tho first or seconi year they should valy the monotony of wheat-growing by the cultivation of potatoes and vegetables, and by tho maintenanc $\rightarrow$ of cattle, pigs and poultry. At the expriment.3 farm at Gleichen I noticed some excellent kitchen garden produce, and in the cxhibition at Winnipeg I saw cabbages and other vegetables which would be no discredit to any unarket garden in England. The maintenance of live stock migth have a small berginning in the keeping of ono or two cows for the sake of milk and butter, and extensions in this direction might be made year by year. Fxcepting in such articles as tea, coffee and sugar, the settler would not find much difliculty after the first year or two in keeping his household table supplied all the year roun $\mathrm{f}$ from tha produce of his farm. 
prairic on for liorse t september k." "Single of them for

rs! Palt of enumerate within connment, or at d from the quired, there er that tree ler a plough lve montlis. t that rivers near, good lity to dwell go nut in in. Weak

ing. Idlers

kers. Men ecause they de no thirid conquers the o field for dy reward,

chielly upon at primitive th 3 settler tome would ng which 1 tart, for at i ho might But a settles. onveniently ont a lete-

effected in ae were the They are icultural de$t$ or seconi potatoes anci exprimental o exluibition to any mar'beginning in ions in this e and sugar, ig his house-
Tho nutritive valıe of $1 l_{1}$. prairie herbayt is sulticiently proved by the fact of its having sustained the vast herds of buicalo which fur ages hare made the prairie their home, but which are now dissappenring before the adsane of cirilisation. Nevertheles: the introduction of cultivated gras.ez would in all probubility lie a step in the right lirection, and the attempt would nost likely b: justifiel hy the success which would follow it. Although much of the land appears capable of growing wheat for an indefinite period. yet thos 3 settlers whose means would allow of it wuild I think do well to sow a portion of their land with good Euglish grass seeds after the third or fouth year. Such grasse.; as cocksfoot, foxtail moadow fescue and timothy, together wilh white and purple clover and a little black medick suggast thamselves as de.irable, hat every eflort should be made to secure clean seed. It is an interesting fact $t h a t$ th tre are no true clovers native to the prairie, although many species of tho milk-vetsh. A itrugalus. ale met with.

The more mixed farming extends on the prairies the suore intoresting will the settlers find it, and the less dopondent will they h: upon the prices they will from year to year secure for thoir wheat. The establishment of flour mills in the North. West will lessen the cost of llour and of oatmeal, will the facilities afforled by the railway nust continue to enable them to compete on favourable terms with $t h \div$ other wheat-exporting countries of the world. Artificial feeding stuff. like artificial fertilsers belong to a future period.

There is no carcity of timber or of fuel, for vast forest are at dillerent spots touched by the railway. Moreover, it is absolutely certain that extensive coalbearing reginns exist in many easily accessible points of ths North-West, some of the coal, as ia the Saskatchewan valley near Medecine Hat, being ubtainable by open workings. the coal cropping out at the surface. Not only will the North-West continu capable of meeting its own demands for mineral fuel, but in a short time it will probably b3 in a position to export conl.

Through the prairie is destitute of trees it is not destined to remain so. Erery settler should plant belts of poplar and other trees about his homestead. They will break the force of the wind, afford grateful shelter to live stock, and do much towards relieving the monotony of the plain. The work might be progressive, a few trees bein ; planter each year, but it is detail that should not bo neglected. In the rolling country beyond Calgary, and in the foothills of the Rockies, where pastoral farming will probab?r constitute the main industry, much ground shelter is available for live siock.

As to the prospecis of the Great North.We.t, it is o zly the prot whe can any :

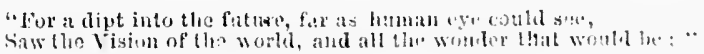

but if its development in the near futur may be at all gouged by its prosress in the immediate past, then will its growtl be rapid indeed. Men who go out there determined to work will, as the years roll on, find themselves in a much batter position than they can hope to secure in the old country, and when the time comes for then to enjoy a wellearned rest in their declining years they will find that they liave got the menn to easible them to do so. And the children who are burn and bred in the haply prairie homea, who will see around them on every side the triumph 3 of man's industry, who are rearod in the bracing atmosphere of a northern sky, they cannot fail to be liealthy and vigorous.

"Iron jointerl, supule-sincw"d they shall dive, and t! "y shall run,"

4

and, true " prairio flowers," tney will grow into men and women possessed of a plyysiqu which could never bave been acquired under the sunnier, more southern, and more ener 
vating climes whiter so many efforts are made to attract British settlers-scions; of the nation which has conquered aud colonised a larger portion of the earth's surface than all other nations taken together.

ONTARIO.

The province of Ontario is so wall known that little reed be said about it here. Uceupying an area greater than that of France, extending farther southward than any other part of the Canadian Dominion, and bounled on two of its three sides by the great freshwater lakes of Iluroa, Erie and Ontario, it enjoys advantages of position, soil and climate, which have combined to render it agricuturally, commercially, and financially, the premier province of Canada. The beautiful capital, T'oronto, "tho Qucen City of the West," is thoroughly Engliah in appearance and churacter, and it is a genuine treat to walk through its broad open streets, to inspect the busy shops, and to rub shoulders with the genial, healthy-looling people who are oridently proud of their metropolis. The bustling, thriving towns in this happy province are too many to particularise, but it 13 not necessary for an agriculturist to spend much time in Ontario before becoming fa. rourably inipressed with the condition of its farming industries. That the sturdy pioreers of agricalture in thle province had to face many natural dificulties is abuncantly shown in the tracts of yet uncleared lorest land which are here and there to be seen, in the tree stmups amongst which the plonghs have on many a farm yet to find their way and in the suake fences which at once appeal by sontrast to the eye of any one who is familiar with the hedge-rows of Olt Fingland.

The agricuiture of Ontario is woic varied than that of any other part of the Dominion. The crops include wheat, balley oats and rye, Indian corn, buckweat, peay and beans. Roots are cultivated to a considerable extend, but hardly so succesfully as in England, through the extension of stock farming will donbtless be reflected in improved yields of roots. The average yields this year, taken over the whole province, in bushels pex acre are : of fall wheat, 21 ; spring wheat, 20 ; barley, 25 ; oats, 36 ; rye, 16 (this crop was abominably poor); peas, 24 ; beans, 22 ; and of hay and clover, 1 ; tons per acre. On the leased farms the average rent per acre is two dollars and seventy-five cents (equivalent to 11 s. 6. d.), the highest rents being in the country of Durham where they average three dollars and fifty-five cents(equivalent to $14 \mathrm{s.9}$. d.), and the lowest in the county of Muskoka, 88 cents per acre (4 s. 1. d.). The wages for farm lands, with board, range between $\$ 196$ a year in Algoma county, and \$149 in Welland county, the average being $\$ 175$ (equivalent to $£ 37$ a year or about 143. a week, with board.) Without board the wages rauga between $\$ 305$ and $\$ 231$ a year, the average being $\$ 257$ (equivalent to $£ 53$. 13s. a year, or slightly over $£ 1$ o week] The average wages of domestic servants are $\$ 1.50$ per week, with board [equivalent to $£ 16$. 5s. a year, with bard.] Farmers in On:ario fin] a difficulty in getting really compo'éd farm liands, and such men can always secure high wages.

Fruit is vry largely grown in the province, ita climate rendering it particularly suitable to fruit culture. Nearly a hundred varieties of apples are coltivated and the produce is largejy exported. Peaches constitute another prominent feature, some of the peach orchards containing as many as 10,000 trees. Grape calture is on the increase, there being more than 3,000 acres of vineyards, chitfly in the southwestern district. Plum, cherres, pears, straw berries and raspberries are likewise extensively grown.

The Ontario farmers aro fully glive to the necessity of raising well-bred live stock, and in this department they approach very closely to the approved practico of stock, farmers at linme. In dairy farming, again, they seem determined not to be left behind in the race, and there are upwards of tive hundred cheese factories in tha province. I may here take the opportinity of expressing my surprise that cheese shouli be so seldon

seen on th I stayed a across the perhaps, $x$ value as $t$ certainly

Ep to the $\mathrm{On}$ supporter there be a exerting : of the 1 technical conmonodi Of the 55 wheat, $0:$ education tho leadi little ?un his un $\mathrm{ml}$ Hereord of Jersey Shropshi the High these rep fills the with con day insp siclent of there we too, that Ontario

\section{It}

will pro turning great pr farm to prairie, ing for the east

through Quebec hundre ing cen the the of Mou nestle?. York, Provin the $\mathrm{Gr}$ which of Que 
ions, of the ace than all

seen on the table in Canada. I am speaking quite generally. At most of the places I stayed at cheese did not seem to enter into the dietary at all, and in my long journey across the prairie I do not remember secing any (save what I took will me). It is, perhaps, no exaggeration to say that a pound of good cheese possesses a much nutritive value as two pounds of lean beef, and in places far away from towns cheese should certainly be nore gencrally consumed than, as far as I could ascertain, is the case.

Even a brief notice of Ontariu would be incomplete without a $\mathrm{f}_{t} \mathrm{w}$ words devoted to the Ontario Agricuttural College, situated near the picturesaue town of Guelpl. It is supnorted by the Provincial Government, and is highly croditable to the province, nor cau there be any doubt that it is quietly and unobtrukively, but none the less rffectively, excrting a powerful ir.1luence for good on the agriculture of Ontario, and of otfier yarts of the Dominion as wall. Tha state subsidy enables it to ofler to future farn:crs a good technical training, both in the theory and practice of their husiness. The college is a commodious edifice, and the farm building and the appurtenances are very complete. Of the 550 acres comprisod in the farm 400 are under cuttivation, the cropping including wheat, oata, barley, peas, hay, roots, pasture and corn forlder. The stock vards have the educational value of an agriculturat show, including, as they do, pedigree animals of ali the leading breeds. Hore, under the sunny sky of Southern (Ontario, where the gay little 'umming birds flit from flower to llower by day and the whip poor-will trolls uut his un mistakeable notes at night, may ho seen splendid specimeus of shorthorns Hereords and 1)evone, of Aberdeen Pulle, Galloways, Ayreilires and West Higlander, of Jerseys, Guerneeys and the ponderons Dutch cattie, while of sheep the Su uthdewn Shropshirc, IIampshire and Oxford Downs, the Linculns, the Ieicester's and tha Cotswolds, the Highlands and the Cleviots are all represented. The selection and fine condition of these representative animals reflect; no little eredit on Profesor Brova, who so ably fills the Chair of Anticulture in the college, and to whese ear the farmers of Ontario may with confrdence eutrust the techuical training of their sous. Although 1 spent a wholu day inspectine the culloge an the farn under the joint wnidance of the controus President of the institutiov, Mr. James MIille, MI. A., and Professir Brown, I yct $f_{t}$ lt that, there were many other things I would, fain hare seen had time permitted. I woull too, that my space allowed me to give a fuller notice of this admirable institution, Ontario may well be proud of her agricultural college.

It is to the emigrant who has a fair amount of capital at command that Oatario will prove most attractive. Many of the younger agricrlturists of this province are turning their faccs westward, desirous of throwing their lut in with the chances of that great prairie region which has been described. In a measure the change frosu an Ontario farm to a prairie farm is les pronounced than from an English lomested to one on the prairie, and as desirable farms come into the market in Ontario it seens a natural proceling for them to be taken up by men of sufticient capital who are newiy arrived from the east.

THE PROYINCE OF QUEHEC

In journeyivg from Ontario to Nova Scotia the traveller mey lay down his route through such important cities as Toronto, Ottawa, Montreal and Quebec. Though Quebec is the capital city of the Province of the same name, the city of Montreal, two hurdred miles higher up the St-Lawrence, is much larger and is a more important trading centre. The commanding site of Quebec city is surpassingly beautiful and has been the theme of many a brillant essaye. Montreal, likewise. as viewed from the summit of Mount Royal, between the foot of which and the banks of the St. Lawrence the city nestler, is seen to occupy an enviable position ; it is almost exactly due north of NewYork, frown which city it is 400 miles distant. Both Montreal and Quebec, are in the Province of Quebec, and there are at present two lines of railsiay between these cities, the Grand-Trunk ou the south side of the St. Lawrence, and The North Shore Railway which runs along the northern bank of the samoriver. The population of the province of Quebec is stated at $1,359,027$, of whom no less than $1,073,920$ are of French origin,

of stock

left behind

rovince. I

so seldon 
descendants of the old French settlers who crosed the Atlantic when Canala was an appanage of the French crown. The French Canadians have preserved their language, their farth and their agriculture to this day, and hence this last ramed feature calls for luat little comment. On either side of the mighty St. Lawrence, from Montreal down as far as Minouski, where the Allan steamera lar $d$ the nails for Canada and take up those for Britain, the winite bouses of the farmsteads of the Fiench Canalian farmers are to be seen in one long strafgling line, - at entervals a town is seen, by the general effect is that of a sparsely populated village hundreds of miles long. The great majorii:" of the towns and villaces nave French namer, many of them of historical interest and association. The anrisultural practices are of a primitive type, and though there is an air colid comfort abont most of the bomesteads, yet the farmers of the St. Lawrence valley seem imbued with little or nore of the progresslve spirit characteristic of the age. I saw men on their knefs cuttin's corn with the sickle; I saw dogra harnessed to little carts in which was farm. wr garden produce. Here and there a bit of really good grazing land attracts the eye, and it is noticenile that at most of the farms a few head of cattle are maintained. The people appear to ho happy and comfortable, fairly woll to do, and content to $\mathrm{j} \cdot \mathrm{g}$ along in the eame grooves as thir fathes smootheil out before them. IIense it is not surprising that those wholave their native land for Canadian shores seldom singer in the Province of Queliec : there is more to a tract them in the dircction of the settling sum, and thither they weal their footsteps.

'There is, however. one partion of Province of Quebec to which the foregoing remarks cannot, in fairness be applie l, that, namely, which extends south and west from the city of Quebec to the United states froutier, to the boundaries of Vermont and NewYork states. This region. known as the Eastern Townships, is from an agricultural point uf viow of a much moro go-ahead character than the rest of tho province. Wild lands for settlement may be obtained on very easy terms, and improved farms may be secured at modernto outlay, so that the new comer who wishes to settle in these parts has considerable cloice before him. The proximity of the New England States ensures a near market for much of the agricultural, and particularly the dairy, produce of this part of Que. bec. Unfortunately, the time at my disphsal did not allow of my visiting the Eastern Toweships, so that $I$ am not in a position to speak very definitely as to their agricultural capabilities nor yet of the inducements they can ofler to settlere.

Ni) Scil scotid.

The Province of Nova Scotia occupies a peninsular position on the east of the Province of New Brunswick, which it adjoins, and to the south of the Gulf of St. Lawrence; Nova Scotia, New Brunswick, and Prince Elward Island conetituting the Maritime Provinces of Canada. Cape Breton, an island to the nortl, is also included in the Province of Nova Scotia, the intire area of which is about 20,000 square smiles, or two-thirds that of Scotland. The long narrow form of the peninsula, and the numerous indentations of the coast-line are such that no part of the province is more than thirty miles distant from the sea. The climate is in the main an iusular one, and r-ore closely resembles that of Evgland, particularly in its humidity, than does that of any other part of Canada. The coldest season of the year is in March, when the east winds blow off the ice-flocs in the Atlantic ; after this the epring rapidly advances.

From Pritain, the most covenielst way to approach Nova Scotia is to sail from liverpool to Halifax, it capital city. The distances 2,855 miles, and the mail steamers make the voyage regularly, all the year round, both winter and summer. Journeying from the west, however, or landing from the steamer at Quebec, the best route from this city, is by the Intercolonial Railway, which from its western terminus at Quebco to its terminus at Halifax, extendy a distauce of 675 miles. The railway passes from Quebec io a north-easterly direction along the south shore of the St. Lawence till Rimouski is reached, when, turning eastwartand sonthward it leaves the Province of Quebes for that of New Brunswick. At Monctov, in the latter province, the line divides, one branch 
la was an languxge, alls for luut yn as far as those for to be seeu is that of the towns iation. The id comfort m imbucel on on their li was farm s the cye, ined. The jog along surprising e Province and thither

foregoing west from and New. cural point Vild Jands be secured luas cousinear marart of Quele Eastern gricultural

st of the alf of St. uting the cluded in smiles, or numerous an thirty re closely ther part ow off the

sail from steamers urneying from this so to its 2uebec in louski is lebe: for le branch going southward as far as St. Joln, the capital of Now Brunswick ard the other tending eastwards through the isthmus into Nova Scotia, across the breailth of which it runs to Halifax. The population of the cntire province is 441 , inif) wlich is less than that of Glasgow.

Ilalifax is a quaint, Engli:li-looking city of zowe forty thousayd inhabitants. It is now the so itaxy place on the American Continent where are English garison is kept, and the old British flace still floats above its citadel. The most primicent feature at Halifax is its magnificent harbour, capable of affording shelter to all the llet ts of the world. It is a great coaling and victualling port oi slips of war and for vessels engaged in the Atlantic trade, and the natural ressouice of the province are such as enable it to meet all the requirements of ships which call at its capital.

Four great industics make demands uron the encogy ant the enterjuise of tho Nova Scotinns, namely, sgriculture, mivirg, slip bulding and firhing; and of the first named of these it will be my duty to speak in rot altogether laudatay terms. The mineral wealih of Nova Scotia is consideralie. Gold occurs in quantity in the od rocks which form the Atlantic horder, is worked it alont twenty places, ihere lieing some interesting gold mines within an casy distance of llalufax, which, through the hindness of Mr. Edwin Gilpin, M. A., Director of Mines for the province, I lad an opportunity of seeing in considerable detail. In 1853 upwards of $t^{2} 6, \mathrm{f} f 0$ worth of goid was exported from the nines of Nova Scotia. Valuable of iron occur, acd are worked at Londonderry and $\mathbf{N} \in \mathbf{w}$ Glargow. Gypsum, or plaster of Paris, is las cely mined, farticularly near llindsor. The province is very rich in coal, and its known freductive coal-fields cover an arca of $6 \$ 5$ square miles. Thie coal is nearly all bituminous, and ome of the sections are of great geological interest, notably those at the Joggins. near siprir rhill, on account of the Jarge and beautifully preserved romains of arcient foms of piant life which they enclose.

It is hardly necessary to grive any details of the ship building and tilhirg interest ; but it will presently be shown that these two industries hare, conntay to what might be expected, exercised and arberse intluence npon the development of agriculture in Nova Scotia.

The agricultural districts lie rather in the westem than in the eastern half of the peninsula, and may be socn in their most typical features around the Basin of Minas and along the Bay of Fundy, particularly in the fertile Anvapolis valley, in the sonthern portion of which sheep are pastureri out all the winter. Most ot the faims occupy sites which were once covered by timber, and much of the "iorest primeval "of whicli Longfellow sings in his pathetic poem may still be seen, interspersed with numerous streanis and lakes abounding in fisl. The inost peculiar features of Nova Scotian acriculture are undoubtedly associnted with the lands bordering the Bay of Fundy. This bay is so situated with respect to the occan, and the conformation of the land which encloses it is such, that the tide in its rise an fall lias a very considerable vertical ranze which is particularly noticeable in the rivers which flow in to the bay. The best analogy to be found in the British Isles is afforded by the river Severn where, in the spring of the year, a high tidal wave rushing up the trumpet shaped estuary gradually gets its waters so croweled together that they form an almost vertical wall as they advance up the narrower parts of the river and produce what is known as the "bore." In the Bay of Fundy, lowever, this happens with every rise of the tide. When the tide is out a great expanse of reddish or brownish fertilising slime may be seen, whish is rapidly covercd with a sheet of water as the tide rises, only again to be left bare and slimy at the next period of low water. I saw these effeets at various places including 'Trviro, Windsor, Grand Pré, and others, and was much impressed with the quantity of slime which can casily be procured and utulized for its excellent fertilising properties. It is on tlie coast lands and on the banks of the rivers that dykes have been erected, chielly of earti on mud, wherely the salt water can be excluded from large areas of land which then become covered with a valuable erbage, and from this is made th 3 sa t-hay or marsh-hay so much valued by the stock farmers of Nova 
Scotia. The roud from Winds sr to Port Williams, on the Cornwallis River passes through to land and Evangiline, and ihe words of longfellow convey a most graplic description of the surrounding:

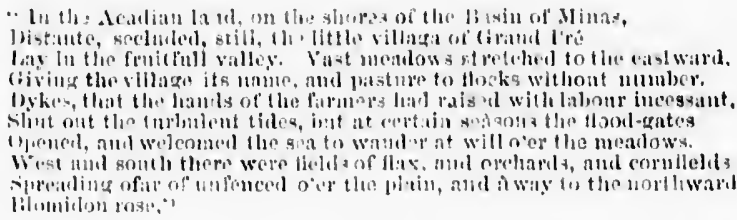

As the spectator surveys the scene with Cape Plomidon in the background, lie realises to the full the truth of these words.

Heary crops of hay are made from the salt grass which grows naturally on the dyke land and marshes. As this hay is much valued by farmers as food for stock I was le! to examine the erowing crop in the marshes near Londonderry and I fonnd it to consist almost entirely of two species of grass and a small species of vetch. The grasses are sipartina cynosuroites. not knowa in England, though I had occssion to mention it as ffcowing on tho praicie, and th, conch grass. Triticnm repens, which has also been previously spoken of. Some specimens of 1 ho latter grass were eritoted, but 1 do not know whether ergot is suthiciontly abundunt to be dangerons to breeding cows. After mowing, the salt hay is curel hy ilragging it up to the higher slops and spreading it out ; it cost ahout $\notin 1$ an acre to make and is worth from $£ 5$ to $£ 6$ a tou in the market, the yich of hay being freanently as much as $2 !$ or 3 tons an acre. Some of the bost dyke jands may bs seen in tho Cornwalis valley were the have sold for as nuch as two,

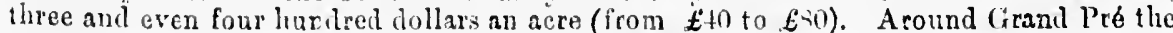
meadow land $i s$. much of it, worth $£ 50$ to $£ 75$ an acre.

The average yield of cercals in the western counties is, in bushels per acre, the following : Of wheat, 14 barley, $3 j^{j}$; oats. $2:+$; rye, 21 ; Indian corn, 42 ; buak wheat, 33. Of hay the average yield comea ilu to tow, tons, hut as much as foar tons per acre of tinothy aras aud clover have b,en taken off in some localities, besid $3 s$ a fair aftermath.

The estimation of bulky produce like turnips, mancels and potatoes, by measure rather than by wight, is a relic of an old practice which Nova Scotia farmers should abaudon, for it is impossible to get either absolute or comparative results of much value by this method. The average produce in bushels per acre of turuips in 420 ; of mangels, 500 ; of potatoes, 250 . In the case of turnips and of mangels, the yield in businels is converted into tons on the assumption that one bushel weighs $(0) \mathrm{lbs}$, but this system of measurement is obviously vage and unsatisfactory ; it belongs to a by-gone period and should be discontinued.

onT The only grass raised from seeds is timothy grass, and when the hay is marketed, the seller is as eager to give as the burer is to deranad, a guarantee that it is clean, pure timothy all through. Iilere, I tink, $i$ i anothes mistaken notion put into practice, and I feel certain that such grasses ae cocksfoot, menlow fescue, and foxtail might be includeil in the mixtures for grass lands in Nova Scotia.

The export of farm produce is steadily increasinu, and last year upwards of one and a half million dol'ars $(s a y \notin 30(0,000)$ worth of such pro luce was shipped. These exports include cattle sent to Europe, potatoes to che United States, and enormons quantities of apples sent across the Atlantic.

point :

'Two ac

busisels which the $15 \mathrm{t}$ and 40 l,e used

to its $\mathrm{f}$ growin presen export chielly

Port

I may

was $p$

for $E$ :

be fill

Youn on ac lars, hood a wer The

wood autu into whil

Mic 
es through description

realises to

turally on r stock I fonnd it atch. Tho to inen. salso been 1 do not Ws. After ng it out ; arket, tlie bost dyke h as two. nd Pré the

acre, the wheat, 33 . r acre of iftermatl.

measure rs stould uch value 120 ; of yield in , but this by-gone

narketed, ean, pure , and I includerl

fone and exports atities of
Stock farning should be a thriving industry in Nova Scotia, its climate and its soil being well adapted to the raising of large herds of cattle and llocks of shoep. It is true that sheep are kept in considerable numbers, and much of the country which, in appearance, is, not altogether dissimilar to tlint which extends betwean Ballinasloe and Galway in Ireland, slould produce mutton equal to that of the Roscommon slieep. But modern slieep farming and the economical production of mutton and wool appear to be points in which the farmers of Nova Sontia still linger behind tho times.

In grazing stock for the English market Nova Scotia possesses a great adrantago over the other provinces of the Dominion. It is the nearest stockraisiug province to Britain, and the,cattle and sheep can be taken on to the stoniners without having to undergo that lowering of the system an $l$ waste of the tissues which are almost inseparable from a long journey, overland, mucli of it by rail. Consequentiy they would reach the British ports in much better condition than those whose travels commence more to the west.

The dairy faruing of the province is improving, and sereral cheese and butter factories are in operatior. I must, liowever, express the surprise I felt when I found American clieese and salt butter placed on the table at more than one place at which I alled in the course of my rambles through this heautifal co'dntry. Surely this ought not to be, particularly in the summer season.

There seems to be no lack of useful laud at very low prices. Tere is a case in point : Dr. Macdonald, of the Londonderry Mines, bought 300 acres at a dollar an acre. Two acres of this land were sown with turnip seed, and yielded batween 1,400 and 1,800 bushels, equivalent to from 18 to 211 tons and ancre. The land was old run out grass land, which was broken up for oats, ard then followed by turnips, the seed being sown between the 15 th and 25 th of June. 'T'he two acres under turnips were dresed with stalle maunre and 1 ewt., of superphosphate per acre. Sheep, are not folded here, and tha roots would l,e used for their winter feed.

Any notice of Nova Scotian agriculture would be incomplete without a reference to its fruit ferming. All along the Annapolis Valley is to be seen one of the finest apple growing regions in the world. Thirty years ago the province was importing apples; at present upwards of a million buklels are grown each year, and enormous quantities are exported to England and elsewhere. A variety known as the Gravenstein is the kind chiefly cultivated ; it is a fair-sized, beautlfuly tinted apple, with srisp, juicy flesh.

Some incuiries made in the course of a drive through the orehard districts around Port Williams enabled me to collect the following facts and figures, hefore detailing which I may mention that a barrel of apples contains three bushels :-Au orchard of 6 acres was pointed out to me which would yield 1,000 barrels of apples, and these would sell for $\$ 500$. The gathering and packing would cost 10 cents a bairel, and 10 barrels might be filled by onfs person in a fair day's work. The barrels cost from 20 to 25 cents each. Young apple trees fit for transplanting cost from 30 cents to $40 \mathrm{conts}$ each, and to plant on acre witn trees at the rate of 40 to the acre involves an outlay of from 25 to $30 \mathrm{dol}$. lars, which inclutes the cost of botll labour and trees. Labourers' wages in the neighborhood range between I dollar and 14 dollar a day in the busy season (from 25s. to 323. a week), and between 60 cents and 70 cents a day in the winter (153. to 17s. a week). The cost of living here is less than in England, and clothing is not much dearer.

Much of the scenery of Nova Scotia is very picturesque, and the alternations of wood and watcr, of rock and fertile grass land, are pleasing to the eye, particularly in the autumn, when the brillant crimson foliage of the maple and the sumach are thrown into bold relief by the dark green li a ves of the pine trees and sombre hues of the cypress, while here and there in the forest oriby the water sille may be seen the tents of "the Micmac.Indians, who still linger in the presence of a civilisation which can find no place 
for them. A drive around the outekirts of the liustling town of Truro, at the heal of Cobequid Bay, a part of the Basin of Minas, gave me an opportunity of seeing rome attractive farms, whose occupants evidently apjeared desirous of keeping abreast with the times. And at Windsor, which lies a consideral,le distance to the gouth-west of Truro, on the River Avon, I was enabled through the courtesy of the Sheriff, to drive over a wide expanse of country of most fortile description; much of it, indecd, was highly suggestive of rich grazing lands at home. The farms, too, were neat and tidy in appearance, and there was a general air of conifort and content, not only here, lint in other parts of Nova Sectia, which could hardly fail to impress the visitor.

I come now to the discussion, of two important points-tirst as to why the fammers of Nova Scotia are somewhat behind the times in their agricultural practices ; and secondly, as to whother Nova Scotia is a province to which settlers should be advised to emigrate. With regard to the lis pt point, refertnce has alrealy becn mado to the mining, shiplsuildirg and fishing interest of lio provirce, and many of the fasmers are so alserberl in one or another of these industries llat, as was forcibly cxpressed to me by a Nova Scotian gentloman well pualified to give an orinion, lhey do littie more than dabble in farming. When shoals of mackerel or oflif $\mathrm{r}$ fisli come into tho local waters the farm is forsaken for the sea ; when a ship is to be built the labour which should be given

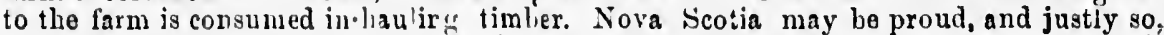
of the half million tons of shipping which were first Inunched upon her water, but it is none the less deplorable hliat her as "leulture should lave to suffer on accourt of its bing; able te enlist on!y a divided interest. It would le wrong, however, to convey the im. pression that all the farmcst are indiflerent to the progrsss of oyriculture, and llie establishment within recent years of a number of local agicultural gocieties certainly indizates a desire for improvement. Major-General Lauric, of Oakfield, Ilalifax, N. S., to whom I am inciebted for considerable in formation, has long :alien a wam interest in the promotion of such iustitutious.

As to whether Nora Scotia offers a good opening for the settler. 1 am ineliacl to answer most unhesitatiogly in the aflirmative. Liven the labourtr wil find $\mathrm{k}$ ere higher wages anit cheaper food then he an get at liome, while the man who can combine a know. ledge of modern fasming wilh the possession of a moderate amount of a capital can liardly fail to derive satisfactory results from the naterials he will find at his disposal. In fact, Nova Scotia is in need of farmers who will give farmin ir the first place in their coneideration, who can bring with them some of the improved practices of modern agriculture, who can intellygently combine pastoral with arable farming, who know zometling of dairying, who understand low to manage and at the same time to improve a flock of sheep, who in laying land'down to grass will not rest their faith solely in timothy, and who in estimating tho yields of their root crops will discard the bushel incarure in favour of the weighing machine. If there be any such men who are tired of the old country, or who may not be Iatiffied with the prospect before them in case they stay all their fives at home, and who feel they possess sufficient "grit " to enable them to smile at the difliculties and inconveniences which must always at first surround the settler in a new country, I would earnestly commend to their notice the advantages offered by Nova Scotia.

The vas ying prices of different linds of allotments in the province are such as to suit the purses of all comers. Uncleared Crown lands may be bought for less than 2s. an acre. Improved farms of 160 to 150 acres with house and farm buildings may be bought for sums extending from $£ 100$ to $£ 50($ according to the degree of cultivation. Numbers of tidy farmsteads were pointed out to me whicl could be purcinased for 800 or 1,000 dollars ( $\$ 160$ to $\$ 00$ ), and 1 feel not a little confidence in ascerting that young men who possess the requisite kcowledge and are in a position to conmand $£ 5 i 0$ and upwards would in a very short time begin to get a good return on their outlay in this fruitful province.

As in (Matario, so in Nova Scotia, improved farms may be obtained because thuse who w wn them desire to move westward. It is well to remember that men who were

born in pioneers arrive ment tli farmsted old wor

Aliserict 'Tlio anc the Can are at h ir party bolongi excalle llavigat and fro made 1 iny fell minute paid pa The res bestowe herself pider su it. I me the sun will ree assistar

Where 'l'hoso railivas station ensure "hich to all $t$ ing acc withne can str the sar for ne: emingra

will in and th and it cause most opinio posses work labour likely that is 
hend of eing rome preast with t of Truro, ve over a as lighly in appearin otlier

wliy the practices ; be advised lo to the ners are so o me ly a mose than waters the d be given justiy so, , but it is i' its bi ins: the ju. I the estartainly 111 . , N. S., to rest in l]e

scliacd to ere higlier te a knowcan liardly 1. In fact, cousiderriculture, ething of flock of othy, and in favour untry, or their lives $t$ the diflilew coun. va Scotia.

unch as to Ian 2s. an s may be ltivation. for 800 or at young $£ 500$ and $y$ in this born in the Canadian provirceg, the sung or grandeuns of men whu were themselves pioneere, are likely to be imbued mose strongly with the pionecr sp. itit than thuse who arrive fresh from the eastesn side of the Allantic, and it sctms appropriate araarcement that new settlers who possess the nocessary capital shoulil take up and improve the farmsteads which years ago were liewn out of the wildernese liy earliersettlers from the old word.

\section{'JHE ULTWARI) JUL'RNIV}

The conveniences of mclem travel are snch that the emigrant's jum ney to Forth. America is deprived of neasly all the hardkhips that were at une time nseociated lhere with. The ance dreaded sea voyage cow cceupies littla more than a week from Liverpool to the Canadian port, arrived whereat, the uflicials of the Canedian Immiuratiun Department are at haxd to giveall aclvice and assistance necessary for the desfatch of cach cmigrant wr party to the desired destination. I crossed thes Atlantic and the mail :tram, hip l'cristin, belonging to the Allan Line, and desire to place on recosd ny apprcciation of the general excellence of the accommodatios providch, and of the still wilh which theze stenners are navigated. A largo number of emigranty occupicil tho stecroge and intermediatesections. and from pereoral inquiry 1 fould that lluy were well iatisfied with the astas gements made for their comfort, and with the goot and liheral diec placed at their disyosal. Anong my fellow passengess in tho salon whs a $13 d y$, who, in the course of tha voyage inspected minutely all tho details of ranagement in $\|_{1}$ intermeciate and siferage Eections, and paid particular attention every day to the cliaractes aod yuality of the lood supplied. The results of her investigations lil her 10 spesk in warm lems uf approval of the care hestowed even upon the pourest passengers, and, as the mothel ol' a growa up family herself, she would be qualilied to examise evesylhise with a critical ye, so that I cunsider such an opinion inuch more valuable than my owe, and on glat to be able to quote

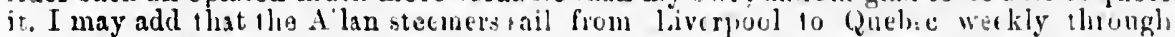
the summer, and to IIalifax all the year sound, ant thist emigrants anding at Quelsec will receive from Mr. Stallord, the Dominion Agent a: Ihat city, erely attention and. assistance that lis long experirrce can sregest.

Emigrants intending to sttle in Nora s.otia yuuhl, of course sail for llalifax, where they would find themselves within, at mo:t, a d?a)'s jomncy of their destination. 'llose lowever, who are bound for the prairie will, on their arrival at Quebec, liave a long railway journey before tliem, travelling day anil niglli, save for stoppégo at certain stations for meals All nelit travelling is not plowant winess cor forcable s'eep can be cnsured, and I wish, therefore, to spesk in high te rus of the "limigrant Slerpin' Cars" which tho Canadian Pacilic liailway autlovities liave, with humano furethouglit, artaclied to all their lonce distance trains. 'The cars are comfortable and comodious, and the sleeping accomodation is based on the same principle as in the l'ullman slecpirif cars, but with no upholstery. With a warm rug or blanket in which to wrap limesclf the traveller can stretch out at full length and get a long refreshing sleep. The nalace sleeping cars of the "same railway ere superbly fitted ; in nne of them, named the "Wabigoon" I travelled for nearly a fortnight and slept soundly and confortably in bed every night. In the emigrant cars there is no extra charge for the sleeping accommodation.

\section{SOIE LAST WORDS}

Those of unr fellow country men who leave the oll countiy to settle in Canada will in time find themselves passing into one of two classes, nanely, lhone who succeed, and thoso who fail. 'The latter, though numerically small, mako a great dcal of nuise and it is perliaps only a trait of liuman nature +hat this man who frils should acribe the cause to anything and everything rather than to timself. It is exceedirgly likely that most of the men who fail in Canada would fail every where else, and I ain strongly of opinion that a vey high percentagie of the men who emigrat possess large or small capital, or no capital at all, are bound to succect if they go to work with a determination to do so, and evince that determination in steady, earucst labour, accompanicd by frugal habits. In no part of the world is agricultural entreprise likely to open up an El Jorado, but there are fair and reasonal,le grounds for asserting that in Canada a man is likely, after yoars of honest toil, to bo in a consirlerably better 
position than be coull ever lanve hopeil to attain from the same expenditure of work. and it may be of capita', at lowe. IIe may easily becomo a land owner out there, but no diflieult it is to be:ome one at home : And tho knowledge that tho work ho does lis the sweat of his lorow is done for himseif, that any inuprovenents he may effect will be improvements of his own e.tate, that there need bo no loase whose rostrietions might hamper is operations, - cellections auch as these canuot fail to weeten his lalour and to uge him to futhar certions. Fisen the man who enn ouly get a fow pounds with which


in timo find himself in a prition to talio up a quaster section (160 acres) on the prairie and the man who can hy his own eflurts work himself in to this rosition is not likely to remain in long, but ti stearily enlarge the mannitude of his mblertakings. I lope I linve, in an earlier part of this Report, made it plain that what would bo regarded as a small capitnl in ()atario or Noves Scotia, would relatively be a large initial eapital on the prairles, and this a di,finction which intendung sttlers would do well to bonr in mind. I

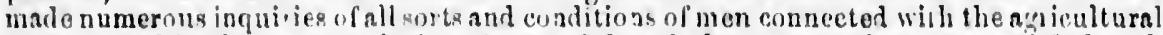
interest, and in the ereat mujority of cases I foumd that new settlers were eatisfied with the clange they had made, and bungand as to their propecte. - the etar of hope olone brightly ahove them. and in it clicerful light they would work and reap tha rawarl of bonest toil. In jto political and ancial institutioss. in many matters relating to eduention and religion. Canada is alead of britain ; knotty phohlems whieh still sorrly vex the miral of the inother contry hase been satisfactorily solved ly this, nne of her fairest daughters, awd ono whose youth is so pregnant with prumise. 'Tho iest guarantee for thin future of Camala is to he soyeth in the history of her liricf pact, and ilose who would fain le ilentified with the development of the great fiture which thesons anul daughtern uf the Domition mean to carve ont for her should hie them westward. "What man lane lone. man can bo" wrote Elyh lhurritt. and when for one man who has in the past

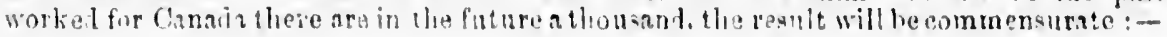



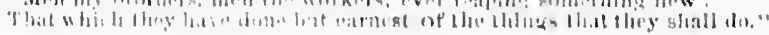

Une more word and I hive done. I am oid-fashioned enough to feel proud at having been born under the linitish llag; it is a privilege l should have been sorry to liave missad. There are, no doubt. many who share my foelings in this matter, and it is a pleasant reflection that, in leaving this scenes of shildhood to found new homes in tho Far West, the settler in Cinali is still shaltered by the amplo folls of tho national flag. In the Dominion he may liold property and accuire all the rights of citizenship without forfeiting his posilion as a British sthject. and withont being sorered as an alien from the kith and kin he has left bihind him.

Before concliding, my Report I desire to express my thanks to many. Canadian friends, on whose lindness I have cncronched while sathering the facts hercir ... forth, and. though 1 forbear to mention their names. I trust that, should these lines ever come under their notice, they will remember that I an not unmindful nor ungreatful. There are two points in the character of the Canadian peoplo which cannot fail to impressany one who may visit this vast area of Greater Britain - these are, their faith in themselves and their contideuce in the future of their country. The moral influence of two such potent factors is bound to accelerato the rapin development which Canada appears destined to undergo, nor can it have other then a salutary eflect upon thoso who more west ward and cast in their lot with these dweller.

College of Agriculture

Dowton. Sali-linir.

November lint

W. FREAM. 
of work. here, but does ly ct will be ns might $r$ and to itli which ages, and he prairic likely to 1. I liope rrded as n tal on the mind. I icultural fied with ope alsone awaril of edincation vex the or fairest antee for lo would laughter' man has the past urate:-

prond at sorry to and it is res in tho onal flag. ) without froni the Canadian ... forth, ver come There are 3 any one elves and sh potent stined to ward and

A.X.

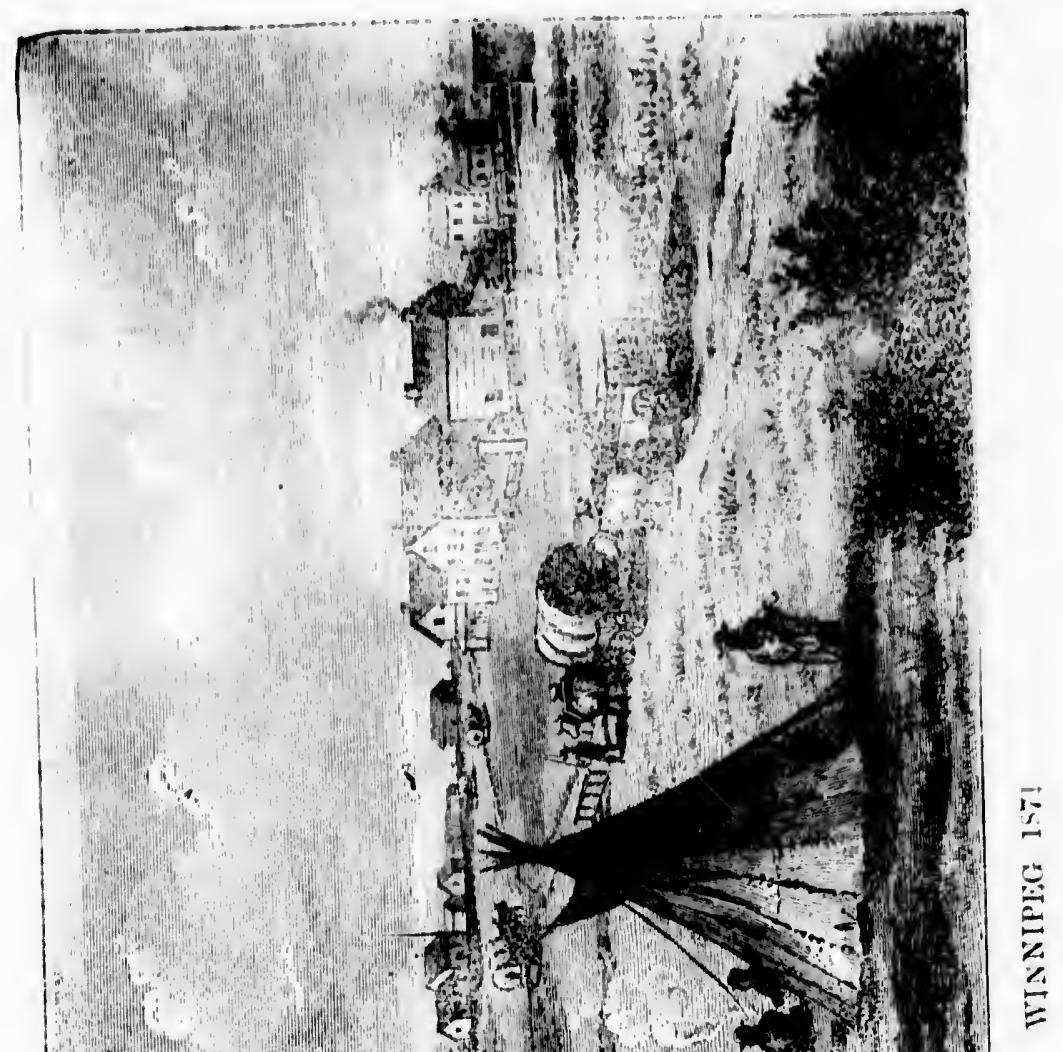




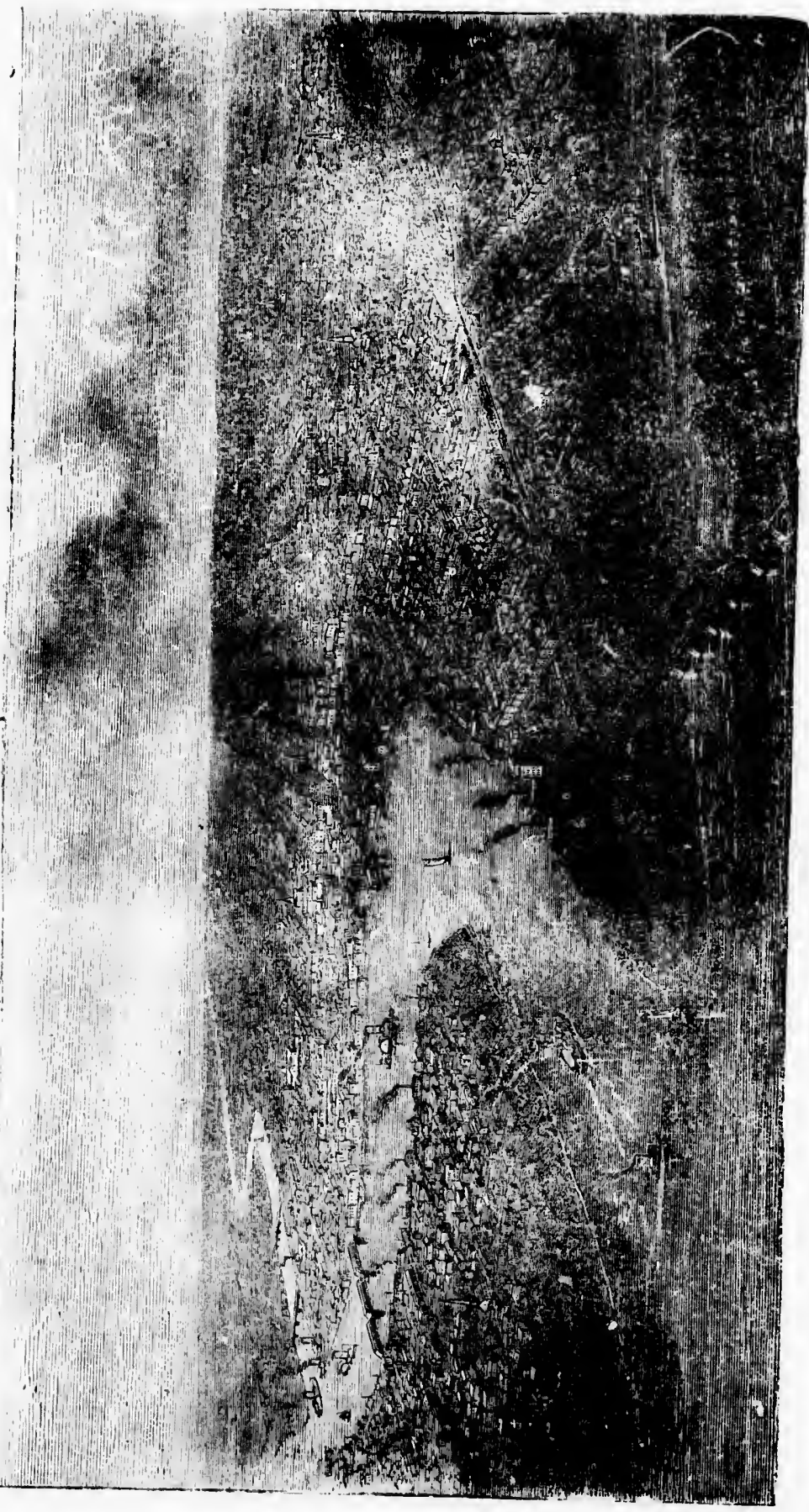

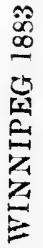




\section{1}

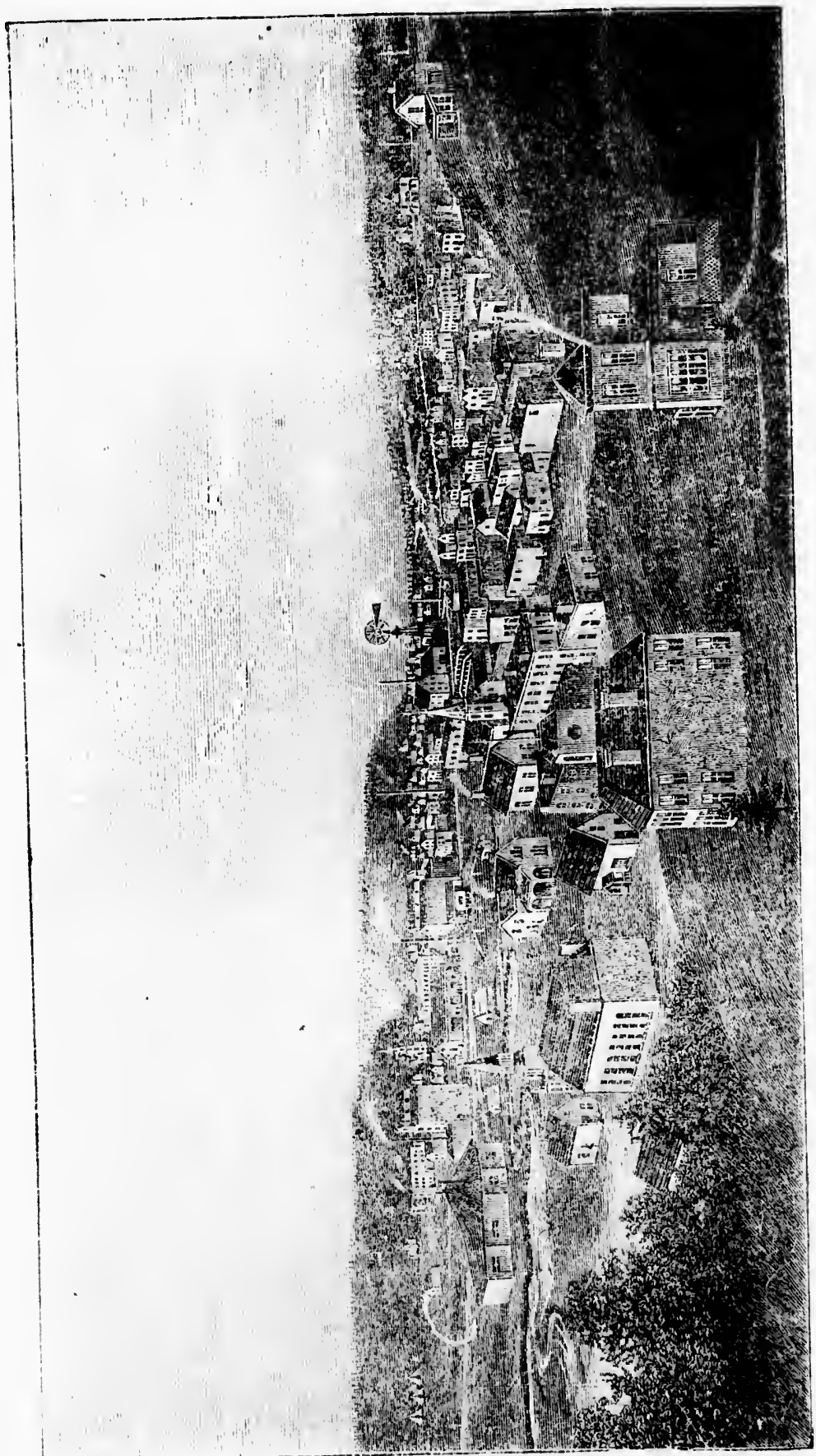




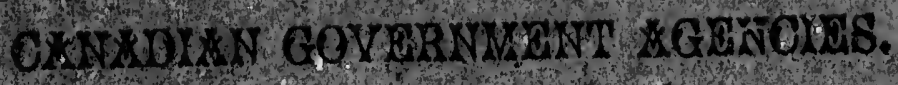

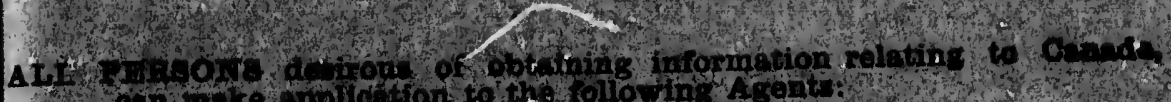

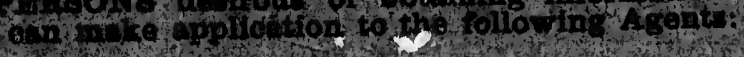

\section{A THE UMTED ktWGDOM.}

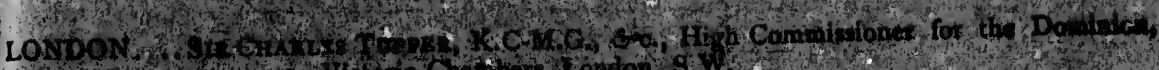



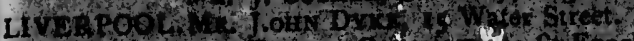

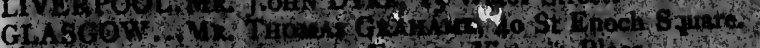





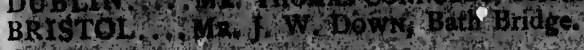

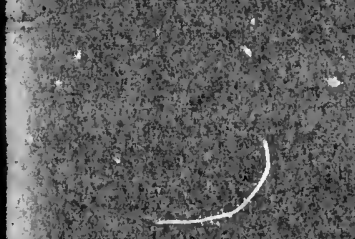

H THE OLD PROVINCES.

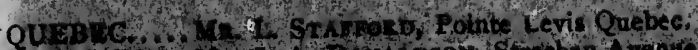

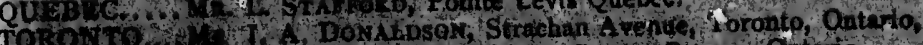

orth W. W J Whis. Wellingtion Strect Ottawh Ontario.

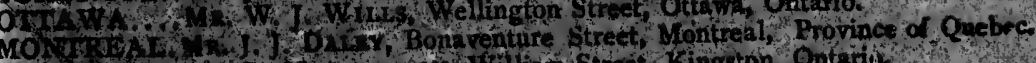



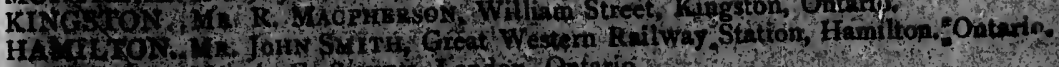



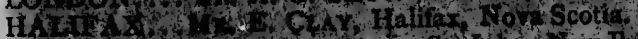



\section{IN NANTTOBA AND THE NORTH WEST.}

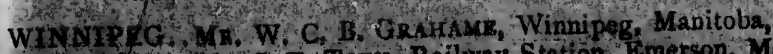

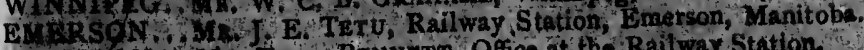

BRAMDON. Wh, THos. BunNitr, Office at the Railway Station.

PORT ARTHOR ...MR J: M, MCGOVER.

\section{IN BRITISH COLVMBFA.}

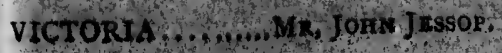

$$
x+1
$$




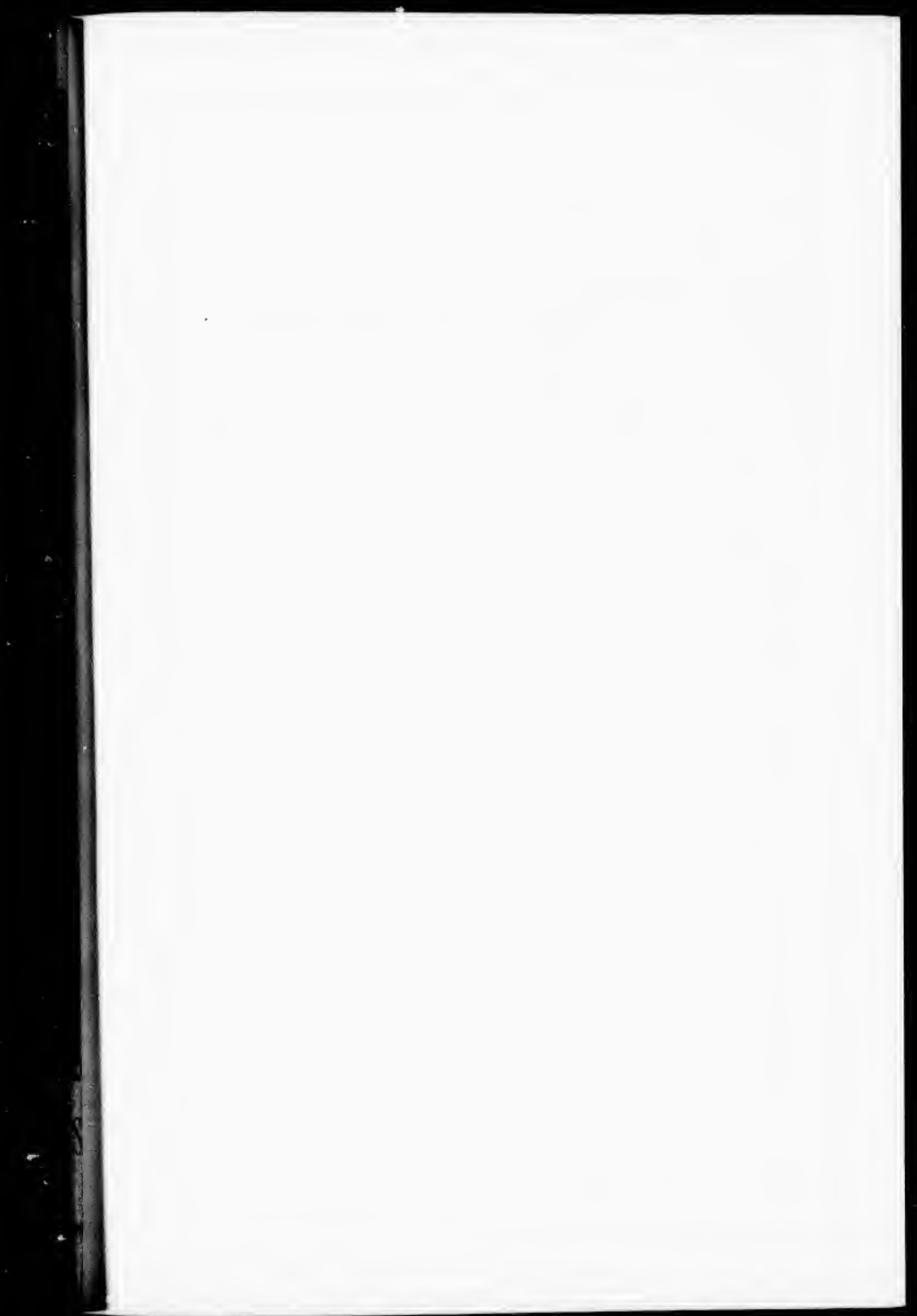




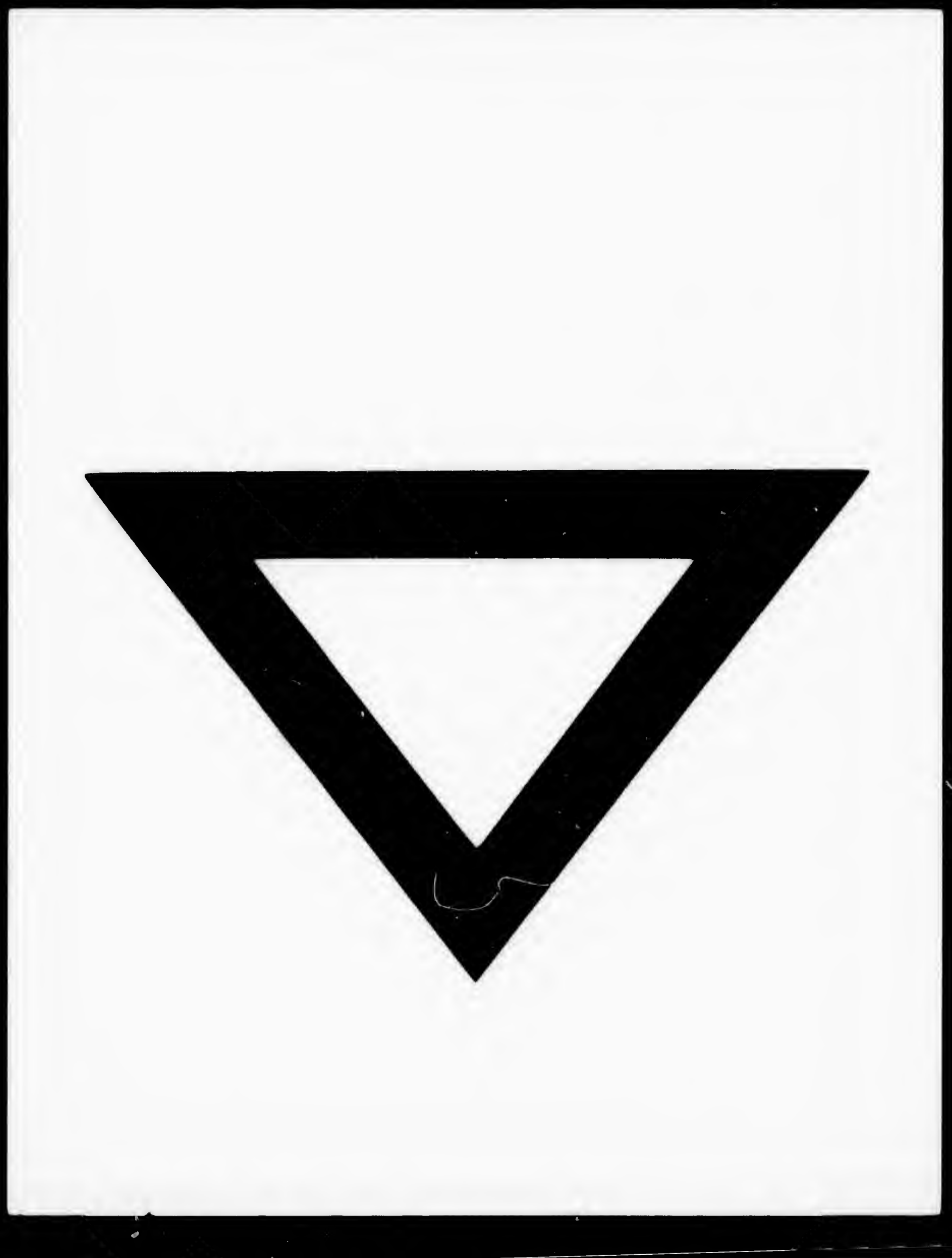

